\title{
Quantifying atmospheric nitrogen deposition through a nationwide monitoring network across China
}

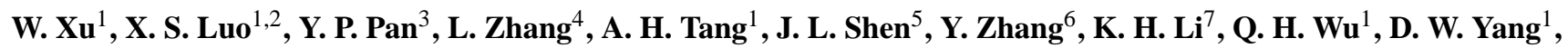

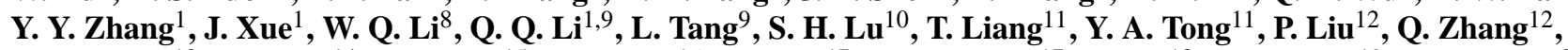
Z. Q. Xiong ${ }^{13}$, X. J. Shi ${ }^{14}$, L. H. Wu ${ }^{15}$, W. Q. Shi ${ }^{16}$, K. Tian ${ }^{17}$, X. H. Zhong ${ }^{17}$, K. Shi ${ }^{18}$, Q. Y. Tang ${ }^{19}$, L. J. Zhang ${ }^{20}$,

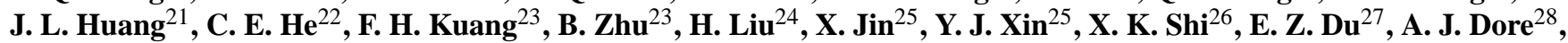
S. Tang ${ }^{28}$, J. L. Collett Jr. ${ }^{29}$, K. Goulding ${ }^{30}$, Y. X. Sun $^{31}$, J. Ren ${ }^{32}$, F. S. Zhang ${ }^{1}$, and X. J. Liu ${ }^{1}$

${ }^{1}$ College of Resources and Environmental Sciences, China Agricultural University, Beijing 100193, China

${ }^{2}$ Institute of Plant Nutrition, Resources and Environmental Sciences, Henan Academy of Agricultural Sciences, Zhengzhou 450002, China

${ }^{3}$ State Key Laboratory of Atmospheric Boundary Layer Physics and Atmospheric Chemistry (LAPC), Institute of Atmospheric Physics, Chinese Academy of Sciences, Beijing 100029, China

${ }^{4}$ Laboratory for Climate and Ocean-Atmosphere Studies, Department of Atmospheric and Oceanic Sciences,

School of Physics, Peking University, Beijing 100871, China

${ }^{5}$ Institute of Subtropical Agriculture, Chinese Academy of Sciences, Changsha 4410125, China

${ }^{6}$ College of Nature Conservation, Beijing Forestry University, Beijing 100083, China

${ }^{7}$ Xinjiang Institute of Ecology and Geography, Chinese Academy of Sciences, Urumqi 830011, China

${ }^{8}$ Fujian Institute of Tobacco Agricultural Sciences, Fuzhou 350003, China

${ }^{9}$ College of Resources and Environmental Sciences, Yunnan Agricultural University, Kunming 650224, China

${ }^{10}$ Soil and Fertilizer Institute, Sichuan Academy of Agricultural Sciences, Chengdu 610066, China

${ }^{11}$ Nature Resource and Environment College, Northwest A\&F University, Yangling 712100, China

${ }^{12}$ Institute of Agricultural Environment and Resource, Shanxi Academy of Agricultural Sciences, Taiyuan 030031, China

${ }^{13}$ College of Resources and Environmental Sciences, Nanjing Agricultural University, Nanjing 210009, China

${ }^{14}$ College of Resources and Environment, Southwest University, Chongqing 400716, China

${ }^{15}$ College of Environmental and Resource Sciences, Zhejiang University, Hangzhou 310029, China

${ }^{16}$ South Subtropical Crops Research Institute, Chinese Academy of Tropical Agricultural Science, Zhanjiang 524091, China

${ }^{17}$ Rice Research Institute, Guangdong Academy of Agricultural Sciences, Guangzhou 510640, China

${ }^{18}$ College of Environmental and Chemical Engineering, Dalian Jiaotong University, Dalian 116028, China

${ }^{19}$ College of Agriculture, Hunan Agricultural University, Changsha 410128, China

${ }^{20}$ College of Resources and Environment, Agricultural University of Hebei, Baoding 071001, China

${ }^{21}$ College of Plant Science and Technology, Huazhong Agricultural University, Wuhan 430070, China

${ }^{22}$ Institute of Geographic Sciences and Natural Resources, Chinese Academy of Sciences, Beijing 100101, China

${ }^{23}$ Institute of Mountain, Hazards and Environment, Chinese Academy of Sciences, Chengdu 610041, China

${ }^{24}$ Research Institute of Soil \& Fertilizer and Agricultural Water Conservation, Xinjiang Academy of Agricultural Sciences, Urumqi 830091, China

${ }^{25}$ The Bureau of Qinghai Meteorology, Xining 810001, China

${ }^{26}$ Agriculture, Forestry and Water Department of Changdao County, Changdao 265800, China

${ }^{27}$ State Key Laboratory of Earth Surface Processes and Resource Ecology, and College of Resources Science \& Technology,

Beijing Normal University, Beijing 100875, China

${ }^{28}$ Centre for Ecology \& Hydrology Edinburgh, Bush Estate, Penicuik, Midlothian EH26 0QB, UK

${ }^{29}$ Department of Atmospheric Science, Colorado State University, Fort Collins, CO 80523, USA

${ }^{30}$ The Sustainable Soils and Grassland Systems Department, Rothamsted Research, Harpenden AL5 2JQ, UK

${ }^{31}$ Institute of Soil and Fertilizer, Anhui Academy of Agricultural Sciences, Hefei 230031, China

${ }^{32}$ Institute of Soil and Fertilizer, Jilin Academy of Agricultural Sciences, Changchun 130124, China 
Correspondence to: X. J. Liu (liu310@ cau.edu.cn)

Received: 17 June 2015 - Published in Atmos. Chem. Phys. Discuss.: 7 July 2015

Revised: 26 October 2015 - Accepted: 27 October 2015 - Published: 9 November 2015

\begin{abstract}
A Nationwide Nitrogen Deposition Monitoring Network (NNDMN) containing 43 monitoring sites was established in China to measure gaseous $\mathrm{NH}_{3}, \mathrm{NO}_{2}$, and $\mathrm{HNO}_{3}$ and particulate $\mathrm{NH}_{4}^{+}$and $\mathrm{NO}_{3}^{-}$in air and/or precipitation from 2010 to 2014. Wet/bulk deposition fluxes of $\mathrm{N}_{\mathrm{r}}$ species were collected by precipitation gauge method and measured by continuous-flow analyzer; dry deposition fluxes were estimated using airborne concentration measurements and inferential models. Our observations reveal large spatial variations of atmospheric $\mathrm{N}_{\mathrm{r}}$ concentrations and dry and wet/bulk $\mathrm{N}_{\mathrm{r}}$ deposition. On a national basis, the annual average concentrations $\left(1.3-47.0 \mu \mathrm{g} \mathrm{N} \mathrm{m}^{-3}\right)$ and dry plus wet/bulk deposition fluxes $\left(2.9-83.3 \mathrm{~kg} \mathrm{~N} \mathrm{ha}^{-1} \mathrm{yr}^{-1}\right)$ of inorganic $\mathrm{N}_{\mathrm{r}}$ species are ranked by land use as urban $>$ rural $>$ background sites and by regions as north China $>$ southeast China $>$ southwest China $>$ northeast China $>$ northwest China $>$ Tibetan Plateau, reflecting the impact of anthropogenic $\mathrm{N}_{\mathrm{r}}$ emission. Average dry and wet/bulk $\mathrm{N}$ deposition fluxes were $20.6 \pm 11.2$ (mean \pm standard deviation) and $19.3 \pm 9.2 \mathrm{~kg} \mathrm{Nha}^{-1} \mathrm{yr}^{-1}$ across China, with reduced $\mathrm{N}$ deposition dominating both dry and wet/bulk deposition. Our results suggest atmospheric dry $\mathrm{N}$ deposition is equally important to wet/bulk $\mathrm{N}$ deposition at the national scale. Therefore, both deposition forms should be included when considering the impacts of $\mathrm{N}$ deposition on environment and ecosystem health.
\end{abstract}

\section{Introduction}

Humans continue to accelerate the global nitrogen $(\mathrm{N}) \mathrm{cy}-$ cle at a record pace as rates of anthropogenic reactive nitrogen $\left(\mathrm{N}_{\mathrm{r}}\right)$ fixation have increased 20 -fold over the last century (Galloway et al., 2008). New $\mathrm{N}_{\mathrm{r}}$ from anthropogenic fixation is formed primarily through cultivation of $\mathrm{N}$-fixing legumes, the Haber-Bosch process, and combustion of fossil fuel (Galloway et al., 2013). As more $\mathrm{N}_{\mathrm{r}}$ have been created, emissions of $\mathrm{N}_{\mathrm{r}}\left(\mathrm{NO}_{x}=\mathrm{NO}+\mathrm{NO}_{2}\right.$, and $\left.\mathrm{NH}_{3}\right)$ to the atmosphere have increased from approximately $34 \mathrm{Tg} \mathrm{N} \mathrm{yr}^{-1}$ in 1860 to $109 \mathrm{Tg} \mathrm{N} \mathrm{yr}^{-1}$ in 2010 (Fowler et al., 2013; Galloway et al., 2004); most of this emitted $N_{r}$ is deposited back to land and water bodies. As an essential nutrient, $\mathrm{N}$ supplied by atmospheric deposition is useful for all life forms in the biosphere, and may stimulate primary production in an ecosystem if it does not exceed the ecosystem-dependent critical load (Liu et al., 2010, 2011). However, long-term high levels of atmospheric $\mathrm{N}_{\mathrm{r}}$ and its deposition can reduce biological diversity (Clark and Tilman, 2008), degrade human health (Richter et al., 2005), alter soil and water chemistry (Vitousek et al., 1997) and influence the greenhouse gas balance (Matson et al., 2002).

Nitrogen deposition occurs via dry and wet processes. Neglecting dry deposition can lead to substantial underestimation of total flux as dry deposition can contribute up to two-thirds of total $\mathrm{N}$ deposition (Flechard et al., 2011; Vet et al., 2014). For quantification of atmospheric deposition at the national scale, long-term monitoring networks such as CAPMoN (Canadian Air and Precipitation Monitoring Network, Canada), CASTNET/NADP (Clean Air Status and Trends Network/the National Atmospheric Deposition Program, United States), EMEP (European Monitoring and Evaluation Programme, Europe), and EANET (Acid Deposition Monitoring Network in East Asia) have been established; such networks are essential for quantification of both wet and dry deposition and revealing long-term trends and spatial patterns under major environmental and climate change (Skeffington and Hill, 2012). Wet deposition, by means of rain or snow, is relatively easily measured in existing networks. In contrast, dry deposition of gases and particulate matter is much more difficult to measure, and strongly influenced by factors such as surface roughness, surface wetness, and climate and environmental factors (Erisman et al., 2005). Direct methods (e.g., eddy correlation, chambers) and indirect methods (e.g., inferential, gradient analysis) can determine dry deposition fluxes (Seinfeld and Pandis, 2006). The inferential method is widely used in many monitoring networks (e.g., CASTNET and EANET), where dry deposition rates are derived from measured ambient concentrations of $\mathrm{N}_{\mathrm{r}}$ species and computed deposition velocities (Endo et al., 2011; Holland et al., 2005; Pan et al., 2012). Additionally, atmospheric modeling has been used as an operational tool to upscale results from sites to regions where no measurements are available (Flechard et al., 2011; Zhao et al., 2015).

According to long-term trends observed by the above monitoring networks, $\mathrm{N}$ deposition has decreased over the last 2 decades in Europe (EEA, 2011). Measurements of wet deposition in the United States show a strong decrease in $\mathrm{NO}_{3}-\mathrm{N}$ deposition over most of the country (Du et al., 2014), but $\mathrm{NH}_{4}-\mathrm{N}$ deposition increased in agricultural regions. China, as one of the most rapidly developing countries in East Asia, has witnessed serious atmospheric $\mathrm{N}_{\mathrm{r}}$ pollution since the late 1970s (Hu et al., 2010; Liu et al., 2011). Accurate quantification of $\mathrm{N}$ deposition is key to assessing its ecological impacts on terrestrial ecosystems (Liu et al., 2011). Previous modeling studies (e.g., Dentener et al., 2006; Gal- 


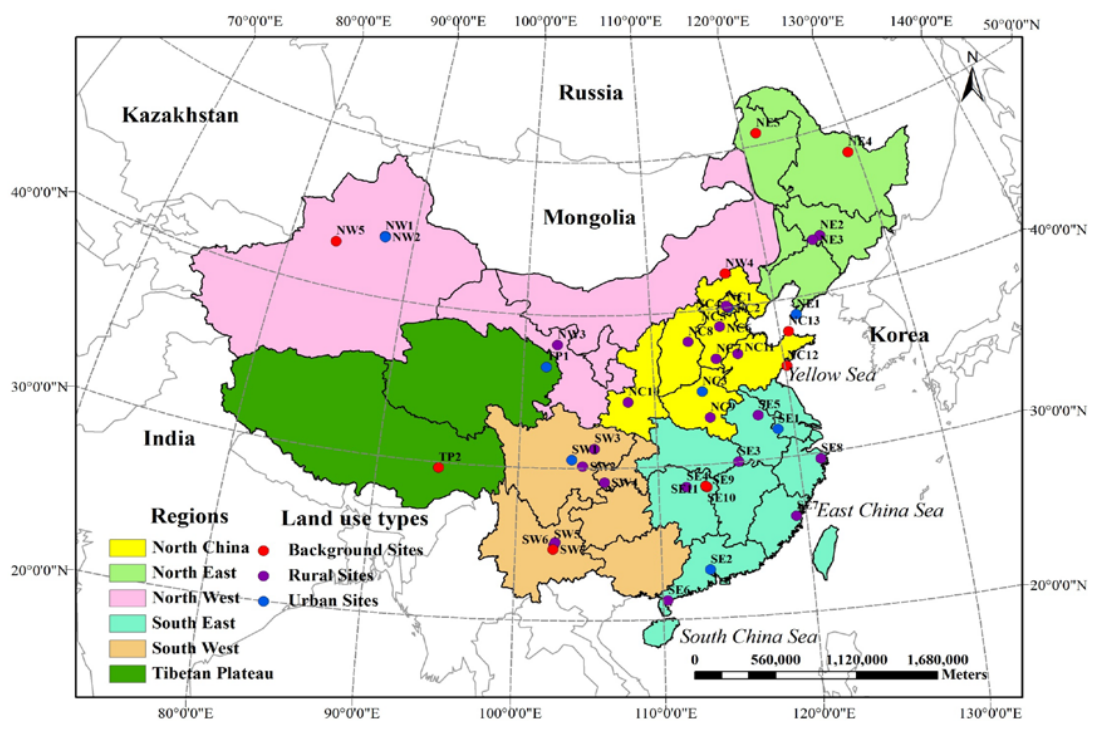

Figure 1. Geographical distribution of the 43 monitoring sites in China.

loway et al., 2008; Vet et al., 2014) suggested that centraleast China was a global hotspot for $\mathrm{N}$ deposition. More recently, based on meta-analyses of historic literature, both Liu et al. (2013) and Jia et al. (2014) reported a significant increase in N wet/bulk deposition in China since the 1980s or 1990s. However, most measurements in China only reported wet/bulk deposition (e.g., Chen and Mulder, 2007; Huang et al., 2013; Zhu et al., 2015) and/or dry deposition (Luo et al., 2013; Shen et al., 2009; Pan et al., 2012) at a local or regional scale. Although national $\mathrm{N}$ deposition has been investigated by Lü and Tian $(2007,2014)$, the deposition fluxes were largely underestimated due to the inclusion only of gaseous $\mathrm{NO}_{2}$ in dry deposition, and not $\mathrm{NH}_{3}, \mathrm{HNO}_{3}$, particulate ammonium and nitrate, etc. Therefore, the magnitude and spatial patterns of in situ measured $\mathrm{N}$ wet/bulk and dry deposition across China are still not clear.

Against such a background, we have established a Nationwide Nitrogen Deposition Monitoring Network (NNDMN) in China since 2010, measuring both wet/bulk and dry deposition. The NNDMN consists of 43 in situ monitoring sites, covering urban, rural (cropland), and background (coastal, forest, and grassland) areas across China. The focus of the network is to conduct high-quality measurements of atmospheric $\mathrm{N}_{\mathrm{r}}$ in gases, particles, and precipitation. These data provide a unique and valuable quantitative description of $\mathrm{N}_{\mathrm{r}}$ deposition in China, but have never been published as a whole. The objectives of this study were therefore to (1) obtain the first quantitative information on atmospheric $\mathrm{N}_{\mathrm{r}}$ concentrations and pollution status across China, and (2) analyze overall fluxes and spatial variations of $\mathrm{N}$ wet/bulk and dry deposition in relation to anthropogenic $\mathrm{N}_{\mathrm{r}}$ emissions from different regions.

\section{Materials and methods}

\subsection{Sampling sites}

The distribution of the 43 monitoring sites in the NNDMN is shown in Fig. 1. Although sampling periods varied between sites, most of our monitoring started from 2010 to 2014 (see Supplement for details). The NNDMN comprises 10 urban sites, 22 rural sites, and 11 background sites (Table S1 of the Supplement). To better analyze atmospheric $\mathrm{N}$ deposition results among the sites, we divided the 43 sites into six regions: north China (NC, 13 sites), northeast China (NE, 5 sites); northwest China (NW, 6 sites), southeast China (SE, 11 sites), southwest China (SW, 6 sites), and the Tibetan Plateau (TP, 2 sites), representing China's various social-economical and geo-climatic regions (for details, see Sect. S1 of the Supplement). The sites in the six regions are described using region codes (i.e., NC, NE, NW, SE, SW, TP) plus site numbers such as NC1, NC2, NC3, NE1, NE2, etc. The longitudes and latitudes of all 43 sites ranged from 83.71 to $129.25^{\circ} \mathrm{E}$, and from 21.26 to $50.78^{\circ} \mathrm{N}$, respectively. Annual mean rainfall ranged from 170 to $1748 \mathrm{~mm}$ and the annual mean air temperature ranged from -6.2 to $23.2{ }^{\circ} \mathrm{C}$. Site names, land use types and population densities are summarized in Table S1 of the Supplement. More detailed information on the monitoring sites, such as specific locations, surrounding environment and possible emission sources are provided in Sect. S2 of the Supplement.

\subsection{Collection of gaseous and particulate $N_{r}$ samples}

In this study ambient $\mathrm{N}_{\mathrm{r}}$ concentrations of gaseous $\mathrm{NH}_{3}$, $\mathrm{NO}_{2}$ and $\mathrm{HNO}_{3}$, and particulate $\mathrm{NH}_{4}^{+}\left(p \mathrm{NH}_{4}^{+}\right)$and $\mathrm{NO}_{3}^{-}$ $\left(p \mathrm{NO}_{3}^{-}\right)$were measured monthly at the 43 sites using con- 
tinuous active and passive samplers. DELTA active sampling systems (DEnuder for Long-Term Atmospheric sampling; described in detail in Flechard et al., 2011 and Sutton et al., 2001) were used to collect $\mathrm{NH}_{3}, \mathrm{HNO}_{3}, p \mathrm{NH}_{4}^{+}$and $p \mathrm{NO}_{3}^{-}$; $\mathrm{NO}_{2}$ samples were collected using Gradko diffusion tubes (Gradko International Limited, UK) at all sampling sites. The air intakes of the DELTA system and the $\mathrm{NO}_{2}$ tubes were set at a height of $2 \mathrm{~m}$ above the ground (at least $0.5 \mathrm{~m}$ higher than the canopy height) at most sites. At a few sites, the DELTA systems could not be used due to power constraints. Therefore, $\mathrm{NH}_{3}$ samples were collected using ALPHA passive samplers (Adapted Low-cost High Absorption; designed by the Center for Ecology and Hydrology, Edinburgh, UK), while the $p \mathrm{NH}_{4}^{+}$and $p \mathrm{NO}_{3}^{-}$in $\mathrm{PM}_{10}$ were collected using particulate samplers (TSH-16 or TH-150III, Wuhan Tianhong Corp., Wuhan, China). However, $\mathrm{HNO}_{3}$ measurements were not performed due to lack of corresponding passive samplers. Briefly, all the measurements of $\mathrm{N}_{\mathrm{r}}$ concentration were based on monthly sampling (one sample per month for each $\mathrm{N}_{\mathrm{r}}$ species) except at the very few sites without DELTA systems, where $p \mathrm{NH}_{4}^{+}$and $p \mathrm{NO}_{3}^{-}$samples were calculated from daily sampling transformed to monthly averaged data. Detailed information on measuring methods, sample replication and collection are given in Sect. S3 of the Supplement with sampling periods listed in Table S2 of the Supplement. Comparisons between the ALPHA samplers and the DELTA systems at six network sites for gaseous $\mathrm{NH}_{3}$ measurements indicated that the two methods provided comparable $\mathrm{NH}_{3}$ concentrations (values between the two methods were not significantly different) (cf. Sect. S4 in the Supplement and Fig. S1 therein).

\subsection{Collection of precipitation}

At all monitoring sites precipitation (here we define it as wet/bulk deposition, which contains wet and part dry deposition) samples were collected using precipitation gauges (SDM6, Tianjin Weather Equipment Inc., China) located beside the DELTA systems (ca. $2 \mathrm{~m}$ ). The collector, consisting of a stainless steel funnel and glass bottle (vol. 2000$2500 \mathrm{~mL}$ ), collects precipitation (rainwater, snow) without a power supply. Precipitation amount was measured using a graduated cylinder (scale range: $0-10 \mathrm{~mm}$; division: $0.1 \mathrm{~mm}$ ) coupled with the gauge. After each daily (08:00-08:00 next day, Greenwich Mean Time +8 ) event, the collected samples were thoroughly mixed and then immediately stored in clean polyethylene bottles $(50 \mathrm{~mL})$. All collected samples (including melted snow) samples were frozen at $-18^{\circ} \mathrm{C}$ at each site until delivery to the laboratory at China Agricultural University (CAU) for analysis of inorganic $\mathrm{N}\left(\mathrm{NH}_{4}^{+}\right.$and $\left.\mathrm{NO}_{3}^{-}\right)$. The gauges were cleaned with high-purity water after each collection and once every week in order to avoid cross contamination.

\subsection{Analytical procedures}

In CAU's analytical laboratory, the exposed sampling trains of the DELTA systems and passive samples were stored at $4{ }^{\circ} \mathrm{C}$ and analyzed at 1 -month intervals. The $\mathrm{HNO}_{3}$ denuders and alkaline-coated filters were extracted with $10 \mathrm{~mL}$ $0.05 \% \mathrm{H}_{2} \mathrm{O}_{2}$ in aqueous solution. The $\mathrm{NH}_{3}$ denuders and acid-coated filters, and ALPHA samplers were extracted with $10 \mathrm{~mL}$ high-purity water. The loaded $\mathrm{PM}_{10}$ filters were extracted with $50 \mathrm{~mL}$ high-purity water by ultrasonication for 30-60 min and then filtered through a syringe filter $(0.45 \mu \mathrm{m}$, Tengda Inc., Tianjin, China). Ammonium $\left(\mathrm{NH}_{4}^{+}\right)$and nitrate $\left(\mathrm{NO}_{3}^{-}\right)$in the extracted and filtered solutions were measured with an AA3 continuous-flow analyzer (Bran+Luebbe $\mathrm{GmbH}$, Norderstedt, Germany). The detection limits were $0.01 \mathrm{mg} \mathrm{N} \mathrm{L}^{-1}$ for $\mathrm{NH}_{4}^{+}$and $\mathrm{NO}_{3}^{-}$. It should be noted that $\mathrm{NO}_{3}^{-}$was converted to $\mathrm{NO}_{2}^{-}$during the chemical analysis. Therefore, $\mathrm{NO}_{2}^{-}$here was included in the analysis, and $\mathrm{NO}_{3}^{-}$ is equal to the sum of $\mathrm{NO}_{2}^{-}$and $\mathrm{NO}_{3}^{-}$. The disks from the Gradko samplers were extracted with a solution containing sulfanilamide, $\mathrm{H}_{3} \mathrm{PO}_{4}$ and $\mathrm{N}$-1-Naphthylethylene-diamine, and the $\mathrm{NO}_{2}^{-}$content in the extract determined using a colorimetric method by absorption at a wavelength of $542 \mathrm{~nm}$. The detection limit for $\mathrm{NO}_{2}^{-}$was $0.01 \mathrm{mg} \mathrm{N} \mathrm{L}^{-1}$. Three laboratory and three field blank samples were extracted and analyzed using the same methods as the exposed samples. After correcting for the corresponding blanks, the results were used for the calculation of ambient concentrations of gaseous and particulate $\mathrm{N}_{\mathrm{r}}$. Each collected precipitation sample was filtered with a $0.45 \mu \mathrm{m}$ syringe filter, and $15 \mathrm{~mL}$ filtrates frozen and stored in polypropylene bottles until chemical analysis within 1 month. The $\mathrm{NH}_{4}^{+}$and $\mathrm{NO}_{3}^{-}$concentrations of the filtrates were determined using an AA3 continuous-flow analyzer as described above.

\subsection{Deposition flux estimation}

The inferential technique, which combines the measured concentration and a modeled dry deposition velocity $\left(V_{\mathrm{d}}\right)$, was used to estimate the dry deposition fluxes of $\mathrm{N}_{\mathrm{r}}$ species (Schwede et al., 2011; Pan et al., 2012). The concentrations of gases $\left(\mathrm{HNO}_{3}, \mathrm{NO}_{2}\right.$, and $\left.\mathrm{NH}_{3}\right)$ and aerosols $\left(\mathrm{NH}_{4}^{+}\right.$ and $\mathrm{NO}_{3}^{-}$) were measured as described in Sect. 2.2. The monthly average $V_{\mathrm{d}}$ over China was calculated by the GEOS (Goddard Earth Observing System)-Chem chemical transport model (CTM) (Bey et al., 2001; http://geos-chem.org). The GEOS-Chem CTM is driven by GEOS-5 assimilated meteorological data from the NASA Global Modeling and Assimilation Office (GMAO) with a horizontal resolution of $1 / 2^{\circ}$ latitude $\times 2 / 3^{\circ}$ longitude and $6 \mathrm{~h}$ temporal resolution ( $3 \mathrm{~h}$ for surface variables and mixing depths). We used a nested-grid version of GEOS-Chem for Asia that has the native $1 / 2^{\circ} \times 2 / 3^{\circ}$ resolution over East Asia $\left(70-150^{\circ} \mathrm{E}, 11^{\circ} \mathrm{S}-\right.$ $55^{\circ} \mathrm{N}$ ) (Chen et al., 2009). The nested model has been applied to examine atmospheric $\mathrm{N}$ deposition to the northwest- 
ern Pacific (Zhao et al., 2015), and a similar nested model for North America has been used to analyze $\mathrm{N}$ deposition over the United States (L. Zhang et al., 2012; Ellis et al., 2013). The model calculation of dry deposition of $\mathrm{N}_{\mathrm{r}}$ species follows a standard big-leaf resistance-in-series model as described by Wesely (1989) for gases and Zhang et al. (2001) for aerosol. For a detailed description of the $V_{\mathrm{d}}$ calculation as well as the estimation of $\mathrm{N}$ dry deposition, the reader is referred to the Supplement (Sect. S5), with monthly and annual dry deposition velocities of $\mathrm{N}_{\mathrm{r}}$ for different land use types presented in Tables S3 and S4 therein. The model uses the land map of the Global Land Cover Characteristics Data Base Version 2.0 (http://edc2.usgs.gov/glcc/globdoc2_ 0.php), which defines the land types (urban, forest, etc.) at the native $1 \mathrm{~km} \times 1 \mathrm{~km}$ resolution and is then binned to the model resolution as a fraction of the grid cell covered by each land type. The model $1 / 2^{\circ}$ resolution may coarsely represent the local land characteristics at the monitoring sites. Future work using a single-point dry deposition model as for CASTNET (Clarke et al., 1997) would further improve the dry deposition flux estimates, but that requires concurrent in situ measurements of meteorological variables, which are not available at present.

Wet/bulk N deposition flux was calculated as the product of the precipitation amount and the concentration of $\mathrm{N}_{\mathrm{r}}$ species in precipitation, using the following Eqs. (1) and (2)

$C_{\mathrm{w}}=\sum_{i=1}^{n}\left(C_{i} P_{i}\right) / \sum_{i=1}^{n} P_{i}$,

where $C_{\mathrm{w}}$ is the volume-weighted mean (VWM) concentration ( $\mathrm{mg} \mathrm{N} \mathrm{L}^{-1}$ ) calculated from the $n$ precipitation samples within a month or a year, and the individual sample concentration $C_{i}$ is weighted by the rainfall amount $P_{i}$ for each sample.

$D_{\mathrm{w}}=P_{\mathrm{t}} C_{\mathrm{w}} / 100$

where $D_{w}$ is the wet/bulk deposition flux $\left(\mathrm{kg} \mathrm{Nha}^{-1}\right), P_{\mathrm{t}}$ is the total amount of all precipitation events $(\mathrm{mm})$, and 100 is a unit conversion factor.

\subsection{Statistics}

A one-way analysis of variance (ANOVA) and nonparametric $t$ tests were conducted to examine the differences in the investigated variables between sites (urban, rural, and background) and between the six regions. Linear regression analysis was used to analyze the relationships among annual wet $\mathrm{N}$ deposition flux, annual precipitation amount, and annual VWM concentration of inorganic $\mathrm{N}$ in precipitation. All analyses were performed using SPSS 11.5 (SPSS Inc., Chicago, IL, USA). Statistically significant differences were set at $P$ values $<0.05$.

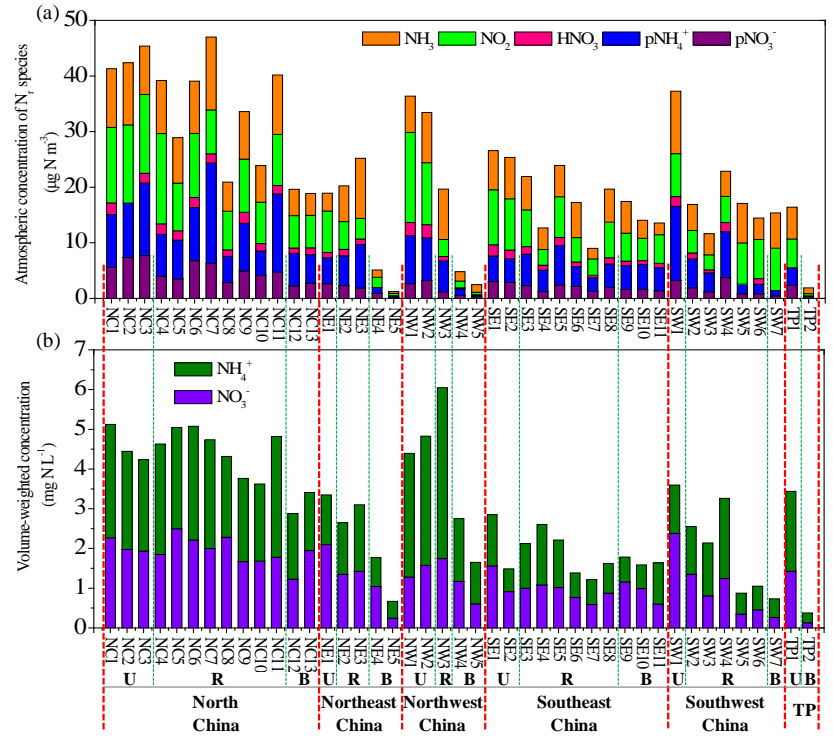

Figure 2. Annual mean concentrations of $\mathrm{N}_{\mathrm{r}}$ compounds in air (a) and volume-weighted concentrations of inorganic nitrogen species in precipitation (b) at all monitoring sites. $\mathrm{U}, \mathrm{R}$, and $\mathrm{B}$ denote urban, rural, and background sites, respectively. TP denotes the Tibetan Plateau.

\section{Results}

\subsection{Concentrations of $\mathrm{N}_{\mathrm{r}}$ species in air}

Monthly mean concentrations of $\mathrm{NH}_{3}, \mathrm{NO}_{2}, \mathrm{HNO}_{3}, p \mathrm{NH}_{4}^{+}$ and $p \mathrm{NO}_{3}^{-}$were $0.08-34.8,0.13-33.4,0.02-4.90,0.02-55.0$ and $0.02-32.1 \mu \mathrm{g} \mathrm{N} \mathrm{m}^{-3}$, respectively (Fig. S2a-e, Supplement). The annual mean concentrations of gaseous and particulate $\mathrm{N}_{\mathrm{r}}$ were calculated for each site from the monthly $\mathrm{N}_{\mathrm{r}}$ concentrations (Fig. 2a), and further were averaged for land use types in the six regions (Fig. 3a-e) and the whole nation (Fig. 4a) according to geographical location and the classification of each site.

Annual mean $\mathrm{NH}_{3}$ concentrations ranged from 0.3 to $13.1 \mathrm{\mu} \mathrm{N} \mathrm{m}^{-3}$, with an overall average value of $6.1 \mu \mathrm{g} \mathrm{N} \mathrm{m}^{-3}$. In $\mathrm{NC}, \mathrm{SE}$, and $\mathrm{SW}$, the $\mathrm{NH}_{3}$ concentrations at the urban sites (average for the three regions, $9.5 \pm 2.1 \mu \mathrm{g} \mathrm{N} \mathrm{m}^{-3}$ ) were about one-third higher than at the rural sites $\left(6.2 \pm 2.3 \mu \mathrm{g} \mathrm{N} \mathrm{m}^{-3}\right)$ and were almost twice of those at the background sites $\left(4.8 \pm 1.4 \mu \mathrm{g} \mathrm{N} \mathrm{m}^{-3}\right)$, whereas in $\mathrm{NE}$ and $\mathrm{NW} \mathrm{NH}_{3}$ concentrations were lower at the urban sites (average of the two regions, $5.5 \pm 3.2 \mu \mathrm{g} \mathrm{N} \mathrm{m}^{-3}$ ) than at the rural sites $\left(8.8 \pm 0.3 \mu \mathrm{g} \mathrm{N} \mathrm{m}^{-3}\right)$ but 4.6 times greater than at the background sites $\left(1.2 \pm 0.5 \mu \mathrm{g} \mathrm{N} \mathrm{m}^{-3}\right)$. Comparing land use types by region, annual $\mathrm{NH}_{3}$ concentrations at the rural sites in northern regions ( $\mathrm{NC}, \mathrm{NE}$, and $\mathrm{NW}$ ) were approximately equal, which on average were 1.8 times greater than the average of southern rural sites. In contrast, annual $\mathrm{NH}_{3}$ concentrations at urban and background sites 

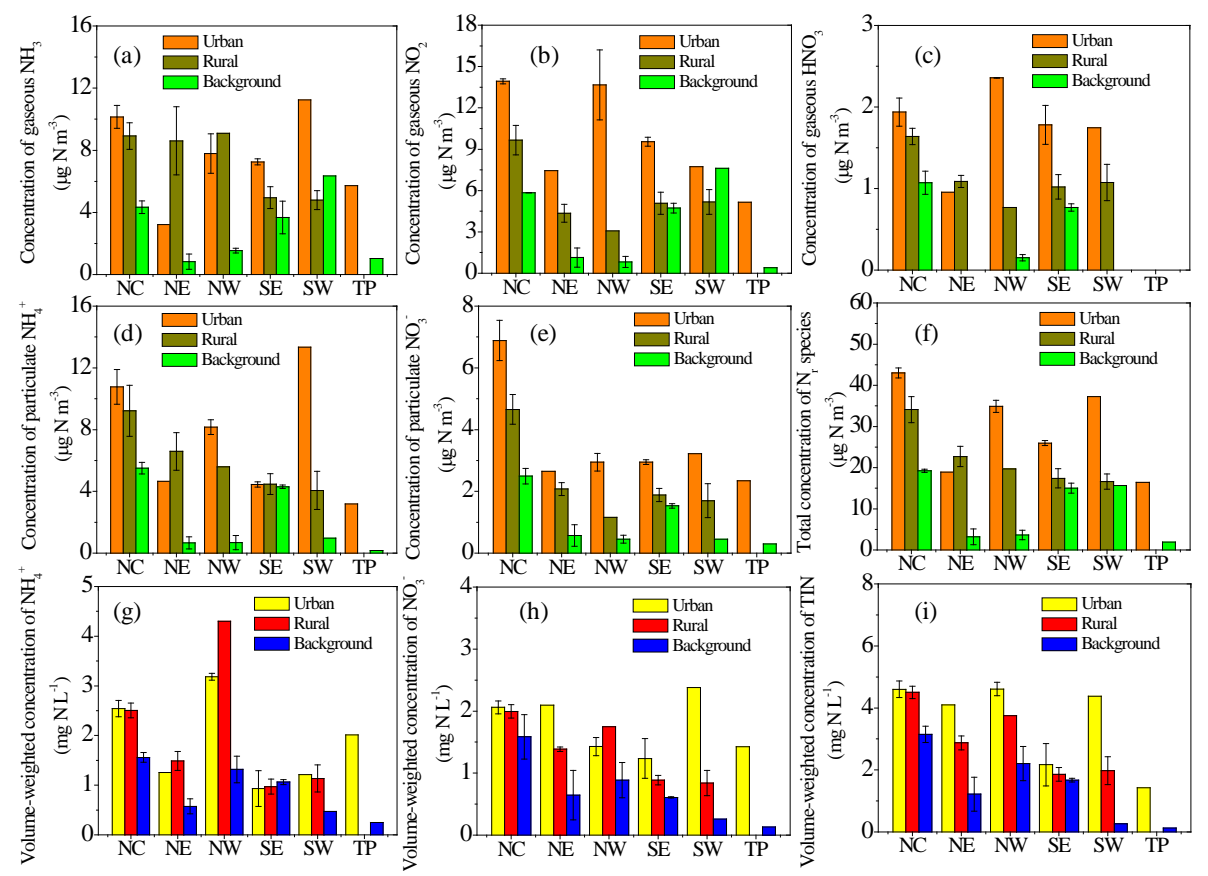

Figure 3. Annual mean concentrations of (a) $\mathrm{NH}_{3}$; (b) $\mathrm{NO}_{2}$; (c) $\mathrm{HNO}_{3}$; (d) $p \mathrm{NH}_{4}^{+}$; (e) $p \mathrm{NO}_{3}^{-}$; and (f) total $\mathrm{N}_{\mathrm{r}}$ : sum of all measured $\mathrm{N}_{\mathrm{r}}$ in air and volume-weighted concentrations of $\mathrm{NH}_{4}^{+}(\mathbf{g})$; $\mathrm{NO}_{3}^{-}$(h) and total inorganic $\mathrm{N}$ (TIN): sum of $\mathrm{NH}_{4}^{+}$and $\mathrm{NO}_{3}^{-}$(i) in precipitation at different land use types in six regions. The number of sites with the same land use type in each region can be found in Table S1 in the Supplement. The error bars are the standard errors of means.

ranked in the order: $\mathrm{SW}>\mathrm{NC}>\mathrm{NW}>\mathrm{SE}>\mathrm{TP}>\mathrm{NE}$, and $\mathrm{SW}>\mathrm{NC}>\mathrm{SE}>\mathrm{NW}>\mathrm{TP}>\mathrm{NE}$, respectively (Fig. 3a).

Annual mean $\mathrm{NO}_{2}$ concentrations showed similar spatial variations $\left(0.4\right.$ to $\left.16.2 \mu \mathrm{g} \mathrm{N} \mathrm{m}^{-3}\right)$ to those of $\mathrm{NH}_{3}$, and overall averaged $6.8 \mu \mathrm{g} \mathrm{N} \mathrm{m}^{-3}$. In the six regions, the $\mathrm{NO}_{2}$ concentrations at urban sites were 1.4-4.5 times higher than those at rural sites, and were even 2.0-16.6 times higher than the background sites (except for SW). By comparison among regions, annual mean $\mathrm{NO}_{2}$ concentrations at rural sites in $\mathrm{NC}$ were about 2.6 times higher than in $\mathrm{NE}$ and $\mathrm{NW}$, and overall averaged $\mathrm{NO}_{2}$ concentrations in northern rural China (NC, NE, and NW; $5.7 \pm 3.5 \mu \mathrm{g} \mathrm{N} \mathrm{m}^{-3}$ ) were comparable to those at southern rural sites (average of SE and SW; $5.1 \pm 0.1 \mu \mathrm{g} \mathrm{m}^{-3}$ ). As for urban and background sites, the annual mean $\mathrm{NO}_{2}$ concentrations followed the order: $\mathrm{NC}>\mathrm{NW}>\mathrm{SE}>\mathrm{SW}>\mathrm{NE}>\mathrm{TP}$, and $\mathrm{SW}>\mathrm{NC}>\mathrm{SE}>\mathrm{NE}>\mathrm{NW}>\mathrm{TP}$, respectively (Fig. 3b).

Annual mean $\mathrm{HNO}_{3}$ concentrations were relatively low everywhere (from 0.1 to $2.9 \mu \mathrm{g} \mathrm{N} \mathrm{m}^{-3}$; average $1.3 \mu \mathrm{g} \mathrm{N} \mathrm{m}^{-3}$ ). In all regions except $\mathrm{NE}$ and $\mathrm{TP}$, the $\mathrm{HNO}_{3}$ concentrations were highest at the urban sites $\left(1.7-2.4 \mu \mathrm{g} \mathrm{N} \mathrm{m}^{-3}\right)$, followed by the rural sites $(0.8-$ $\left.1.6 \mu \mathrm{g} \mathrm{N} \mathrm{m}^{-3}\right)$, and were lowest at the background sites $\left(0.2-1.1 \mu \mathrm{g} \mathrm{N} \mathrm{m}^{-3}\right)$. The $\mathrm{HNO}_{3}$ concentrations were comparable for the same land use types across northern and southern monitoring sites, on average, 1.8 vs. $1.8,1.2$ vs. 1.0 , and 0.6 vs. $0.8 \mu \mathrm{g} \mathrm{N} \mathrm{m}^{-3}$ at the urban, rural, and background sites, respectively (Fig. 3c). The annual mean concentrations of $p \mathrm{NH}_{4}^{+}$and $p \mathrm{NO}_{3}^{-}$were in the ranges of $0.2-18.0 \mu \mathrm{g} \mathrm{N} \mathrm{m}^{-3}$ (average $5.7 \mu \mathrm{g} \mathrm{N}^{-3}$ ) and $0.2-7.7 \mu \mathrm{g} \mathrm{N} \mathrm{m}^{-3}$ (average $2.7 \mu \mathrm{g} \mathrm{N} \mathrm{m}^{-3}$ ), respectively. Annual $p \mathrm{NH}_{4}^{+}$concentrations show a decreasing trend of urban $>$ rural $>$ background in all regions (except NE), where relatively higher concentrations were observed at the rural sites than the urban sites, and in SE, where no clear differences were observed among three land use types (Fig. 3d). In contrast, annual $\mathrm{pNO}_{3}^{-}$concentrations showed a declining trend of urban $>$ rural $>$ background in all regions (Fig. 3e). Overall, annual mean concentrations of both $\mathrm{pNH}_{4}^{+}$and $p \mathrm{NO}_{3}^{-}$at all land use types were both slightly higher in northern China (NC, NE and NW) than in southern China (SE, SW, and TP).

In total, annual mean concentrations of gaseous and particulate $\mathrm{N}_{\mathrm{r}}$ in air were $1.3-47.0 \mu \mathrm{g} \mathrm{N} \mathrm{m}{ }^{-3}$ among all sampling sites. The total annual concentrations of measured $\mathrm{N}_{\mathrm{r}}$ generally decreased on the order of urban $>$ rural $>$ background in all regions except NE (Fig. 3f).

\subsection{Concentrations of $\mathrm{N}_{\mathrm{r}}$ species in precipitation}

The monthly VWM concentrations of inorganic $\mathrm{N}_{\mathrm{r}}$ species at the 43 sampling sites during the study period ranged from 0.01 to $27.1 \mathrm{mg} \mathrm{N} \mathrm{L}^{-1}$ for $\mathrm{NH}_{4}^{+}-\mathrm{N}$ and from 0.02 to $27.9 \mathrm{mg} \mathrm{NL}^{-1}$ for $\mathrm{NO}_{3}^{-}-\mathrm{N}$ (Fig. S3, Supplement). The an- 


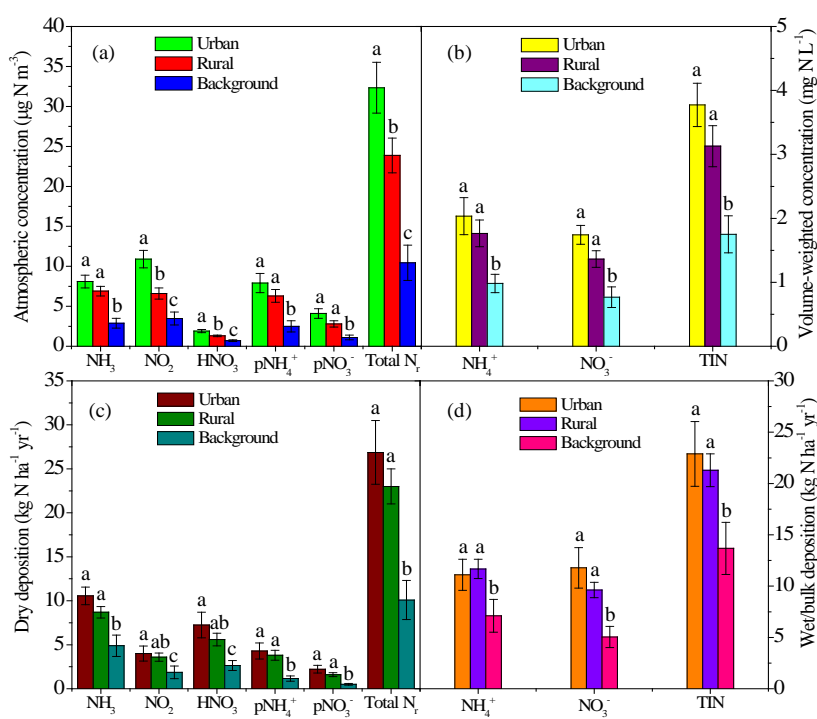

Figure 4. Annual mean concentrations and deposition fluxes of $\mathrm{N}_{\mathrm{r}}$ compounds at different land use types across China: concentrations in air (a); volume-weighted concentrations in precipitation (b); dry $\mathrm{N}$ deposition fluxes (c); wet/bulk $\mathrm{N}$ deposition fluxes (d). The number of sites with the same land use type can be found in Table S1 in the Supplement. The error bars are the standard errors of means.

nual VWM concentrations of $\mathrm{NH}_{4}^{+}-\mathrm{N}$ and $\mathrm{NO}_{3}^{-}-\mathrm{N}$ across all sites were in the ranges of $0.2-4.3$ and $0.1-2.5 \mathrm{mg} \mathrm{N} \mathrm{L}^{-1}$, respectively, with averages of 1.6 and $1.3 \mathrm{mg} \mathrm{N} \mathrm{L}^{-1}$ (Fig. 2b). The urban-rural background distributions of annual VWM concentrations of $\mathrm{NH}_{4}^{+}-\mathrm{N}$ and $\mathrm{NO}_{3}^{-}-\mathrm{N}$ were, respectively, fairly coincided with corresponding reduced (i.e., $\mathrm{NH}_{3}$ and $p \mathrm{NH}_{4}^{+}$) and oxidized $\mathrm{N}_{\mathrm{r}}$ (i.e., $\mathrm{HNO}_{3}$ and $p \mathrm{NO}_{3}^{-}$) in all regions except $\mathrm{NH}_{4}^{+}-\mathrm{N}$ in $\mathrm{SE}$ and $\mathrm{NO}_{3}^{-}-\mathrm{N}$ in $\mathrm{NW}$ (Fig. $3 \mathrm{~g}$ and h). Conversely, the regional variations in annual VWM concentrations of $\mathrm{NH}_{4}^{+}-\mathrm{N}$ and $\mathrm{NO}_{3}^{-}-\mathrm{N}$ for the three land use types were not consistent with corresponding reduced and oxidized $\mathrm{N}_{\mathrm{r}}$, respectively. On a national basis, the VWM concentrations of $\mathrm{NH}_{4}^{+}-\mathrm{N}$ and $\mathrm{NO}_{3}^{-}-\mathrm{N}$ both decreased in the order urban $\geq$ rural $>$ background (Fig. $4 b$ ). The annual total inorganic $\mathrm{N}$ (TIN) concentrations in precipitation across all sites were $0.4-6.0 \mathrm{mg} \mathrm{N} \mathrm{L}^{-1}$, decreasing from urban to background sites in all regions (except NE) as well as on a national basis (Figs. 3i and 4b).

\subsection{Dry deposition of $\mathrm{N}_{\mathrm{r}}$ species}

The dry deposition fluxes of $\mathrm{NH}_{3}, \mathrm{NO}_{2}, \mathrm{HNO}_{3}, \mathrm{NH}_{4}^{+}$and $p \mathrm{NO}_{3}^{-}$were in the ranges of $0.5-16.0,0.2-9.8,0.2-16.6$, $0.1-11.7$, and $0.1-4.5 \mathrm{~kg} \mathrm{Nha}^{-1} \mathrm{yr}^{-1}$, and averaged 8.2, 3.2, 5.4, 3.2, and $1.5 \mathrm{~kg} \mathrm{Nha}^{-1} \mathrm{yr}^{-1}$, respectively (Fig. 5a). The total dry $\mathrm{N}$ deposition across all sites ranged from 1.1 to $52.2 \mathrm{~kg} \mathrm{Nha}^{-1} \mathrm{yr}^{-1}$ (average $20.6 \pm 11.2 \mathrm{~kg} \mathrm{~N} \mathrm{ha}^{-1} \mathrm{yr}^{-1}$ ). Gaseous $\mathrm{N}$ species were the primary contributors to total dry-deposited N, ranging from 60 to $96 \%$, despite the miss-

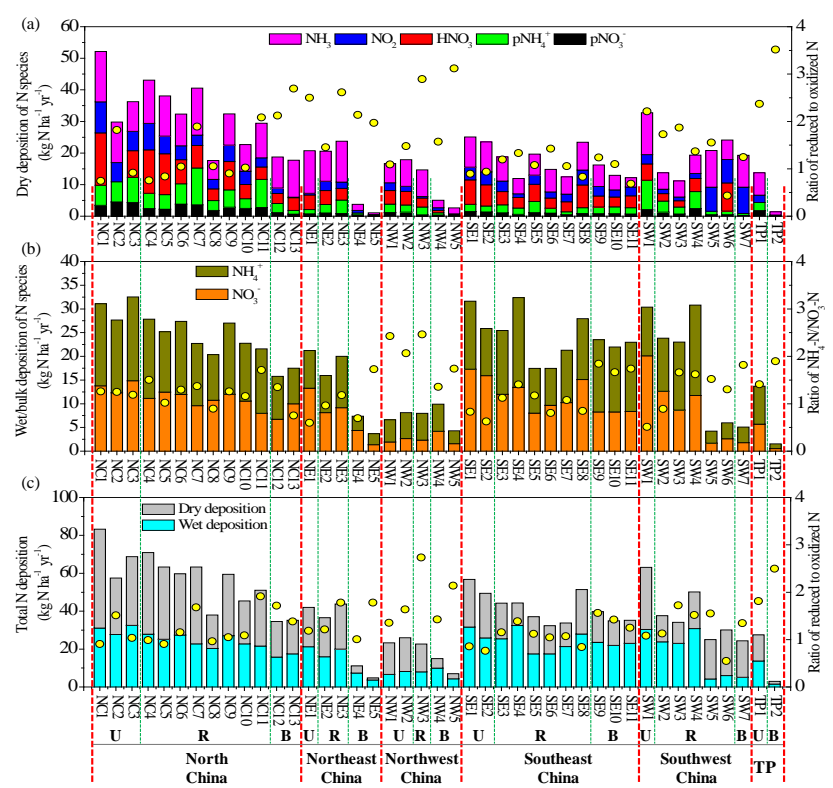

Figure 5. Annual deposition flux of various $\mathrm{N}_{\mathrm{r}}$ species at the 43 selected sites in China: (a) dry deposition flux; (b) wet/bulk deposition flux; (c) total deposition flux. Yellow dots denote ratios of reduced $\mathrm{N}$ to oxidized $\mathrm{N}$ in dry deposition (a), $\mathrm{NH}_{4}^{+}-\mathrm{N}$ to $\mathrm{NO}_{3}^{-}-\mathrm{N}$ in wet/bulk deposition (b) and/or reduced $\mathrm{N}$ to oxidized $\mathrm{N}$ in total deposition (c) at all sampling sites. U, R, and B denote urban, rural, and background sites, respectively. TP denotes the Tibetan Plateau.

ing $\mathrm{HNO}_{3}$ data at a few sites. In general, $\mathrm{NH}_{3}$ was the predominant $\mathrm{N}_{\mathrm{r}}$ species in total dry $\mathrm{N}$ deposition and accounted for $24-72 \%$, compared with $1-43 \%$ from $\mathrm{NO}_{2}$ and $9-37 \%$ from $\mathrm{HNO}_{3}$. Comparing land use types in each region, the spatial pattern of individual fluxes is fairly consistent with that of their respective concentrations except that of $\mathrm{NH}_{3}$ for $\mathrm{NC}$, that of $\mathrm{NO}_{2}$ for $\mathrm{SW}$, those of $\mathrm{NO}_{2}$ and $p \mathrm{NH}_{4}^{+}$for $\mathrm{NW}$, and those of almost all measured $\mathrm{N}_{\mathrm{r}}$ species for NE (Figs. 3ae and $6 \mathrm{a}-\mathrm{e}$ ). Furthermore, a consistent picture is also seen for the total flux (sum of fluxes of five $\mathrm{N}_{\mathrm{r}}$ species) at each land use type (Figs. 5f and 6f). Among the six regions, regional variations of individual fluxes at each land use type generally differed from those of their respective concentrations. Similarly, the inconsistent behavior appeared for the total fluxes at urban and rural sites but not at background site. On a national basis, there was no significant difference $(p>0.05)$ in the total dry $\mathrm{N}$ deposition fluxes between urban $\left(26.9 \mathrm{~kg} \mathrm{Nha}^{-1} \mathrm{yr}^{-1}\right)$ and rural $\left(23.0 \mathrm{~kg} \mathrm{Nha}^{-1} \mathrm{yr}^{-1}\right)$ sites, both of which were significantly higher than background site (10.1 $\left.\mathrm{kg} \mathrm{N} \mathrm{ha}^{-1} \mathrm{yr}^{-1}\right)$. Also, a similar pattern was found for the dry deposition flux of each $\mathrm{N}_{\mathrm{r}}$ species among different land use types (Fig. 4c).

\subsection{Wet/bulk deposition of $\mathrm{N}_{\mathrm{r}}$ species}

Wet/bulk $\mathrm{N}$ deposition fluxes at the 43 sites ranged from 1.0 to $19.1 \mathrm{~kg} \mathrm{Nha}^{-1} \mathrm{yr}^{-1}$ for $\mathrm{NH}_{4}^{+}-\mathrm{N}$ and from 0.5 to 
$20.1 \mathrm{~kg} \mathrm{Nha}^{-1} \mathrm{yr}^{-1}$ for $\mathrm{NO}_{3}^{-}-\mathrm{N}$ (Fig. 5b). The annual wet/bulk deposition fluxes of $\mathrm{NH}_{4}^{+}-\mathrm{N}$ were, on average, 1.3 times those of $\mathrm{NO}_{3}^{-}-\mathrm{N}$. The total wet/bulk N $\left(\mathrm{NH}_{4}^{+}-\right.$ $\mathrm{N}+\mathrm{NO}_{3}^{-}-\mathrm{N}$ ) deposition fluxes across all the sites were $1.5-32.5 \mathrm{~kg} \mathrm{Nha}^{-1} \mathrm{yr}^{-1} \quad$ (average $19.3 \mathrm{~kg} \mathrm{~N} \mathrm{ha}^{-1} \mathrm{yr}^{-1}$ ), with a large spatial variation. Regional variation of annual wet/bulk $\mathrm{N}$ deposition followed the order of $\mathrm{NC}>\mathrm{SE}>\mathrm{SW}>\mathrm{NE}>\mathrm{NW}>\mathrm{TP}$ for $\mathrm{NH}_{4}^{+}-\mathrm{N}$, and $\mathrm{SE}>\mathrm{NC}>\mathrm{SW}>\mathrm{NE}>\mathrm{TP}>\mathrm{NW}$ for $\mathrm{NO}_{3}^{-}-\mathrm{N}$, both of which differed from their orders of annual VWM concentration, reflecting differences in annual precipitation amount. Annual total wet/bulk $\mathrm{N}$ deposition fluxes averaged 24.6, 13.6, 7.4, 24.4, 17.6, and $7.6 \mathrm{~kg} \mathrm{~N} \mathrm{ha}^{-1} \mathrm{yr}^{-1}$, respectively, in NC, NE, NW, SE, SW, and TP (Fig. 5b). At the national scale, annual wet/bulk deposition fluxes of total inorganic $\mathrm{N}$ and/or each $\mathrm{N}_{\mathrm{r}}$ species at urban and rural sites were comparable but significantly higher $(p<0.05)$ than those at background sites (Fig. 4d).

\subsection{Total annual dry and wet/bulk deposition of $\mathrm{N}_{\mathrm{r}}$ species}

The total (dry plus wet/bulk) $\mathrm{N}$ deposition at the 43 sites ranged from 2.9 to $83.3 \mathrm{~kg} \mathrm{Nha}^{-1} \mathrm{yr}^{-1}$ (average $39.9 \mathrm{~kg} \mathrm{Nha}^{-1} \mathrm{yr}^{-1}$ ) for the period, with $23-83 \%$ drydeposited (Fig. 5c). Separated by land use types or regions, total annual mean $\mathrm{N}$ deposition fluxes were 49.7, 44.3 and $26.0 \mathrm{~kg} \mathrm{Nha}^{-1}$ at the urban, rural and background sites, or $56.2,41.7,37.8,27.6,18.8$, and $15.2 \mathrm{~kg} \mathrm{~N} \mathrm{ha}^{-1}$ in NC, SE, SW, NE, NW, and TP, respectively, reflecting different anthropogenic impacts. In our network, the $\mathrm{NH}_{x}$ (i.e., wet/bulk $\mathrm{NH}_{4}^{+}-\mathrm{N}$ deposition plus dry deposition of $\mathrm{NH}_{3}$ and particulate $\mathrm{NH}_{4}^{+}$) / $\mathrm{NO}_{y}$ (wet/bulk $\mathrm{NO}_{3}^{-}-\mathrm{N}$ deposition plus dry deposition of $\mathrm{NO}_{2}, \mathrm{HNO}_{3}$, and particulate $\mathrm{NO}_{3}^{-}$) ratio at urban sites (from 0.8 to 1.8 , averaging 1.2) was not significantly different $(p>0.05)$ from rural (from 0.5 to 2.7 ; averaging 1.3) and background (from 1.0 to 2.5 ; averaging 1.6) sites. On a regional basis, the relative importance of dry vs. wet/bulk $\mathrm{N}$ deposition to the total deposition were different in the six regions, $57 \%$ vs. $43 \%$ in NC, $54 \%$ vs. $46 \%$ in NE, $61 \%$ vs. $39 \%$ in NW, $42 \%$ vs. $58 \%$ in SE, $55 \%$ vs. $45 \%$ in SW, and $50 \%$ vs. $50 \%$ in TP (Fig. 7).

\section{Discussion}

\subsection{Concentration of $\mathrm{N}_{\mathrm{r}}$ species in air and precipitation}

China is facing serious atmospheric $\mathrm{N}_{\mathrm{r}}$ pollution induced by anthropogenic $\mathrm{N}_{\mathrm{r}}$ emissions (Liu et al., 2011, 2013). The present study shows that monthly $\mathrm{N}_{\mathrm{r}}$ concentrations of species, through comparisons among regions, have a distinct spatial variability with values significantly higher (all $p<0.05$ ) in NC and significantly lower (all $p<0.05$ ) in TP. Annual mean $\mathrm{NH}_{3}$ and $\mathrm{NO}_{2}$ concentrations at most sam- pling sites are in good agreement with the emission inventory and satellite observations by $\mathrm{Gu}$ et al. (2012), who reported $\mathrm{NH}_{3}$ hotspots in the North China Plain and southcentral China such as Jiangsu and Guangdong provinces, while $\mathrm{NO}_{x}$ hotspots were mainly in more developed regions such as the Jing-Jin-Ji (Beijing-Tianjin-Hebei), the Yangtze River Delta and the Pearl River Delta. Our results confirm that NC, which consumes large quantities of fertilizers (for food production) and fossil fuel (for energy supply) (Zhang et al., 2010), experiences the most serious $\mathrm{N}_{\mathrm{r}}$ pollution in China; TP is the least polluted region due to much less human activity. When considering different land use types, the average total annual $\mathrm{N}_{\mathrm{r}}$ concentrations ranked urban $>$ rural $>$ background, with significant differences (all $p<0.05$ ) among them, despite site-to-site variability within regions. This reflects the dominant role of human activity on atmospheric $\mathrm{N}_{\mathrm{r}}$.

For individual $\mathrm{N}_{\mathrm{r}}$ species, higher mean concentrations were observed at urban sites than at rural and background sites (Fig. 4a). Higher $\mathrm{NH}_{3}$ concentration in urban areas may be associated with $\mathrm{NH}_{3}$ emissions from biological sources, such as human, sewage disposal systems, and refuse containers (Reche et al., 2012). In addition, $\mathrm{NH}_{3}$ can be produced by over-reduction of NO in automobile catalytic converters (Behera et al., 2013), increasing ambient $\mathrm{NH}_{3}$ concentrations in urban areas with high traffic densities. Between 2006 and 2013, the number of motor vehicles increased from 2.39 to 5.17 million in Beijing and from 0.46 to 1.72 million in Zhengzhou (CSY, 2007-2014), which is likely to have resulted in elevated $\mathrm{NH}_{3}$ emissions. Higher $\mathrm{NO}_{2}$ concentrations are expected in urban areas due to $\mathrm{NO}_{x}$ emissions from the combustion of fossil fuels ( $\mathrm{Li}$ and $\mathrm{Lin}, 2000$ ), and also lead to higher $\mathrm{HNO}_{3}$ concentrations in urban areas via $\mathrm{NO}_{2}$ oxidation.

The higher $p \mathrm{NH}_{4}^{+}$and $p \mathrm{NO}_{3}^{-}$concentrations observed at urban sites mainly resulted from the high concentrations at the northern urban sites (NC1, NC2, NC3, NW1, and NW2) (Figs. 2a and S2d, e in the Supplement). This is probably due to the fact that cities in northern China, such as Beijing and Zhengzhou in NC and Urumqi in NW, are being surrounded by intensive agricultural production. Rapid developments along with urbanization in suburban areas shorten the transport distance between $\mathrm{NH}_{3}$ emitted from agriculture and $\mathrm{SO}_{2}$ and $\mathrm{NO}_{x}$ emitted from fossil fuel combustion (Gu et al., 2014). This allows the pollutants to react more readily and form aerosols (e.g., $\mathrm{PM}_{2.5}$ ), leading to high concentrations of $p \mathrm{NH}_{4}^{+}$and $p \mathrm{NO}_{3}^{-}$near or within cities. This explanation is supported by the recent MEPC (2014) report that the annual average $\mathrm{PM}_{2.5}$ concentrations in the cities of Beijing, Zhengzhou, and Urumqi were more than twice the Chinese annual mean $\mathrm{PM}_{2.5}$ standard value of $35 \mu \mathrm{g} \mathrm{m}^{-3}$, whereas cities such as Guangzhou and Xining with little surrounding agricultural production had lower $\mathrm{PM}_{2.5}$ concentrations. In China's 12th Five Year Plan (2011-2015), nationwide controls on $\mathrm{NO}_{x}$ emissions will be implemented along 

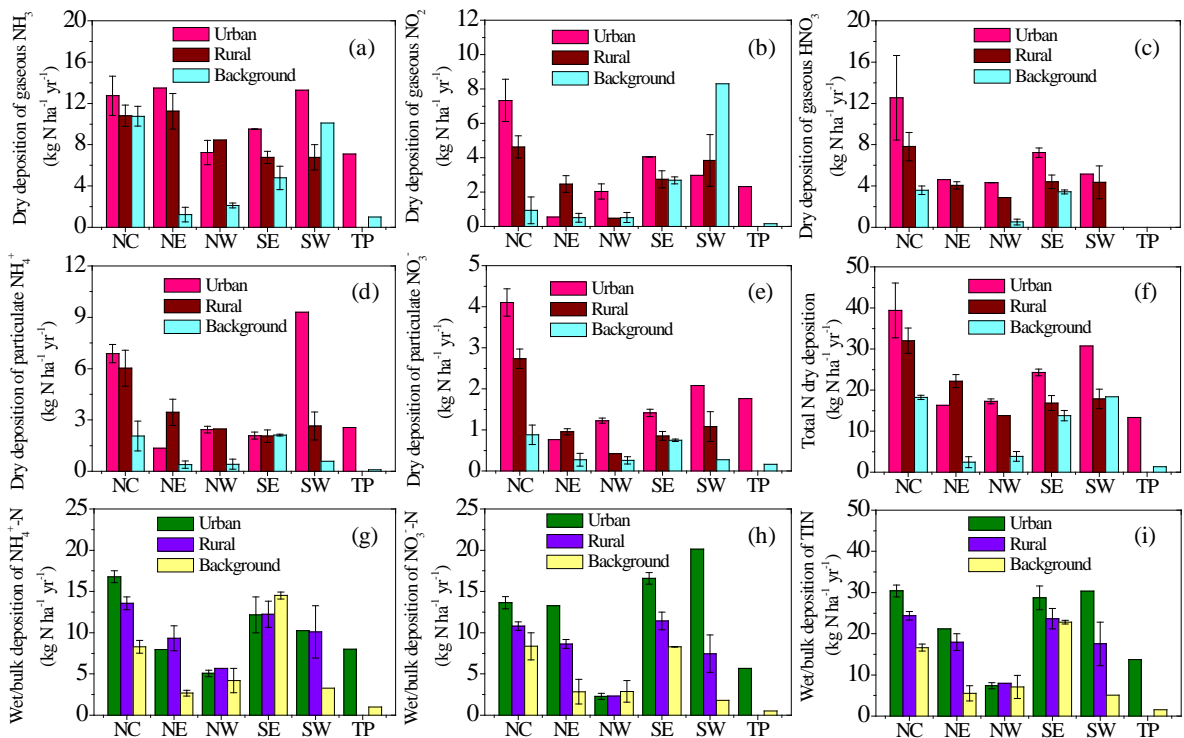

Figure 6. Dry $\mathrm{N}$ deposition fluxes of (a) $\mathrm{NH}_{3}$; (b) $\mathrm{NO}_{2}$; (c) $\mathrm{HNO}_{3}$; (d) $p \mathrm{NH}_{4}^{+}$; (e) $p \mathrm{NO}_{3}^{-}$; and (f) total $\mathrm{N}_{\mathrm{r}}$ : sum of all measured $\mathrm{N}_{\mathrm{r}}$ in dry and wet/bulk $\mathrm{N}$ deposition fluxes of $\mathrm{NH}_{4}^{+}(\mathbf{g}) ; \mathrm{NO}_{3}^{-}$(h) and total inorganic $\mathrm{N}$ (TIN): sum of $\mathrm{NH}_{4}^{+}$and $\mathrm{NO}_{3}^{-}$(i) at different land use types in the six regions. The number of sites with the same land use type in each region can be found in Table S1 in the Supplement. Error bars are standard errors of means.

with controls on $\mathrm{SO}_{2}$ and primary particle emissions (Wang et al., 2014). In order to better improve the regional air quality for metropolitan areas, our results suggest that strict control measures on both $\mathrm{NH}_{3}$ and $\mathrm{NO}_{x}$ would be beneficial in $\mathrm{NC}$, at least in the suburban areas.

Rural sites in this study also had relatively high concentrations of all measured $\mathrm{N}_{\mathrm{r}}$ species in air, altogether ranking in the order of $\mathrm{NC}>\mathrm{NE}>\mathrm{NW}>\mathrm{SE}>\mathrm{SW}$ (Fig. 3f). The higher concentrations in northern China are mainly due to the combined effect of high $\mathrm{NH}_{3}$ emissions from $\mathrm{N}$ fertilized farmland (F. S. Zhang et al., 2008) and urban air pollution (e.g., $\mathrm{NO}_{2}, \mathrm{HNO}_{3}, p \mathrm{NH}_{4}^{+}$, and $p \mathrm{NO}_{3}^{-}$) transported from population centers to the surrounding rural areas (Luo et al., 2013). The lower air concentrations of $\mathrm{N}_{\mathrm{r}}$ species at background sites can be ascribed to the lack of both substantial agricultural and industrial emissions. Additionally, higher wind speeds occurred at some background areas (e.g., NC12, NC13 and NW4) (Table S1, Supplement), favoring the dispersion of atmospheric pollutants.

We found that regional variations in $\mathrm{N}_{\mathrm{r}}$ concentrations in precipitation were not fully in accordance with ambient $\mathrm{N}_{\mathrm{r}}$ concentrations (see Sect. 3.2) when assessed by land use types. It is commonly accepted that $\mathrm{N}$ concentrations in precipitation are affected by the amount of precipitation (Yu et al., 2011). Negative correlations between precipitation amount and monthly volume-weighted concentrations of $\mathrm{NH}_{4}^{+}-\mathrm{N}$ and $\mathrm{NO}_{3}^{-}-\mathrm{N}$ were obtained by fitting exponential models in all six regions (Fig. S4, Supplement), indicating a dilution effect of rainwater on inorganic $\mathrm{N}$ concentration. The relationships were not significant $(p>0.05)$ in NW and
TP, which is probably caused by low precipitation amounts at or near the sampling sites (Fig. S5, Supplement). Nevertheless, dilution could explain some of the regional differences in precipitation $\mathrm{N}$ concentrations.

\subsection{Dry and wet/bulk deposition of $\mathrm{N}_{\mathrm{r}}$ species}

A significant $(p<0.001)$ positive correlation was observed between annual dry $\mathrm{N}$ deposition and total annual concentrations of atmospheric $\mathrm{N}_{\mathrm{r}}$ species across all sites (Fig. S6, Supplement). Therefore, higher concentrations of $\mathrm{N}_{\mathrm{r}}$ species at urban sites led to higher dry deposition rates compared with rural and background sites, mainly attributable to elevated $\mathrm{N}_{\mathrm{r}}$ emissions from urban sources (e.g., non-agricultural $\mathrm{NH}_{3}$ emissions from landfills, wastewater treatments and $\mathrm{NO}_{x}$ emissions from traffic vehicles and power plants) and rapid development of intensive agricultural production in suburban areas surrounding cities, regardless of differences in dry deposition velocities of various $\mathrm{N}_{\mathrm{r}}$ species in different land use types. At the national scale, dry $\mathrm{N}$ deposition rates contributed almost half (23-83\%, averaging $52 \%)$ of the total inorganic $\mathrm{N}$ deposition, indicating the importance of dry deposition monitoring for comprehensive $\mathrm{N}$ deposition quantification.

In this study, regional variations of annual wet/bulk $\mathrm{N}$ deposition fluxes of $\mathrm{NH}_{4}^{+}-\mathrm{N}, \mathrm{NO}_{3}^{-}-\mathrm{N}$ and their sum showed different spatial patterns to those of corresponding annual VWM concentrations of them in precipitation (see Sect. 3.4). These findings, together with no significant differences $(p>0.05)$ in total annual wet/bulk $\mathrm{N}$ deposition between $\mathrm{NC}$ and SE, reflect, not surprisingly, that regional wet/bulk 


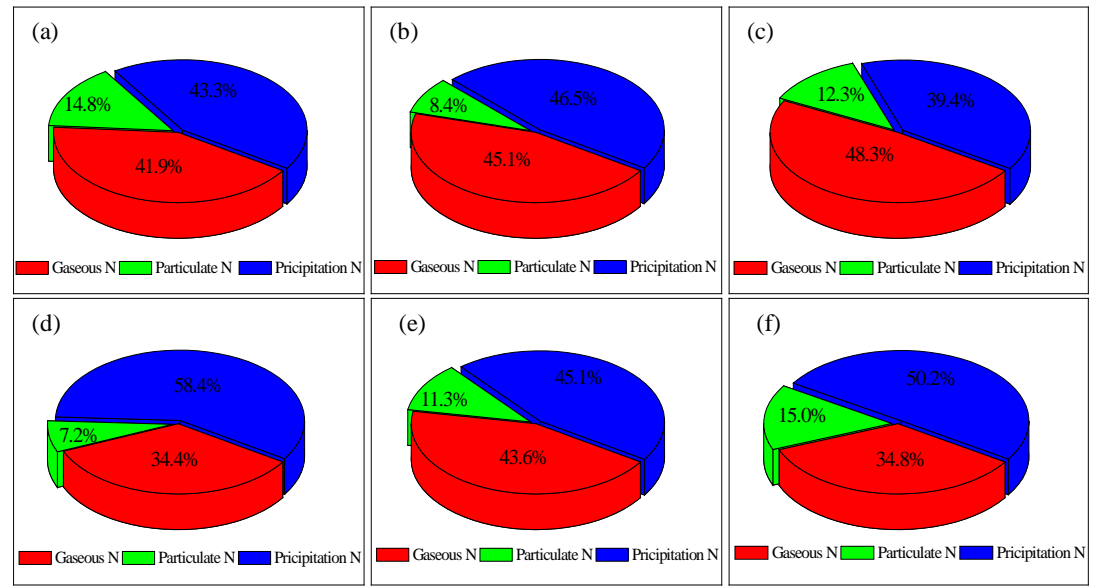

Figure 7. Contribution of different pathways (dry-deposited $\mathrm{N}=$ gaseous $\mathrm{N}+$ particulate $\mathrm{N}$, wet/bulk-deposited $\mathrm{N}=$ precipitation $\mathrm{N}$ ) to the estimated total $\mathrm{N}$ deposition in the six regions: (a) NC: north China; (b) NE: northeast China; (c) NW: northwest China; (d) SE: southeast China; (e) SW: southwest China; (f) TP: Tibetan Plateau.

$\mathrm{N}$ deposition is dependent not only on $\mathrm{N}_{r}$ concentrations in precipitation but also on annual rainfall amounts. As shown in Fig. 8, annual wet/bulk deposition fluxes of $\mathrm{NH}_{4}^{+}-\mathrm{N}$ and $\mathrm{NO}_{3}^{-}-\mathrm{N}$ both showed significantly positive correlations with the corresponding annual VWM concentrations of inorganic $\mathrm{N}$ and annual precipitation amount, especially for $\mathrm{NH}_{4}^{+}-\mathrm{N}$, that more significant was found for precipitation amount than concentration. The measured wet/bulk $\mathrm{N}$ deposition rates (average $19.3 \mathrm{~kg} \mathrm{~N} \mathrm{ha}^{-1} \mathrm{yr}^{-1}$ ) were almost twice the earlier average wet deposition value of $9.9 \mathrm{~kg} \mathrm{Nha}^{-1} \mathrm{yr}^{-1}$ for period of 1990-2003 in China (Lü and Tian, 2007). Our results show similar regional patterns and comparable magnitudes to those measured in the 2000s in China as reported by Jia et al. (2014) ( $\sim 14 \mathrm{~kg} \mathrm{Nha}^{-1} \mathrm{yr}^{-1}$, wet deposition) and Liu et al. (2013) ( $21 \mathrm{~kg} \mathrm{~N} \mathrm{ha}^{-1} \mathrm{yr}^{-1}$, bulk deposition).

The $\mathrm{NH}_{4}^{+}-\mathrm{N} / \mathrm{NO}_{3}^{-}-\mathrm{N}$ ratio in wet/bulk deposition can be used to indicate the relative contribution of $\mathrm{N}_{\mathrm{r}}$ from agricultural and industrial activities to $\mathrm{N}$ deposition (Pan et al., 2012; Zhan et al., 2015; Zhu et al., 2015) because the major anthropogenic source of $\mathrm{NH}_{4}^{+}-\mathrm{N}$ in precipitation is $\mathrm{NH}_{3}$ volatilized from animal excrement and the application of nitrogenous fertilizers in agriculture, while anthropogenic sources of $\mathrm{NO}_{3}^{-}-\mathrm{N}$ in precipitation originate from $\mathrm{NO}_{x}$ emitted from fossil fuel combustion in transportation, power plant, and factories (Cui et al., 2014). In this study the overall annual average ratio of $\mathrm{NH}_{4}^{+}-\mathrm{N} / \mathrm{NO}_{3}^{-}-\mathrm{N}$ in wet/bulk deposition was $1.3 \pm 0.5$ (standard deviation), with an increasing (but not significant) trend for urban (1.2 \pm 0.6$)$, rural $(1.3 \pm 0.4)$, and background $(1.5 \pm 0.4)$ sites (Fig. $5 b)$. Our measured ratio was slightly lower than the average values of 1.6 in Europe (Holland et al., 2005) and 1.5 in the United States (Du et al., 2014), and similar to an average value (1.2) reported elsewhere for 2013 in China (Zhu et al., 2015). Based on these findings, we conclude that $\mathrm{NH}_{4}^{+}-\mathrm{N}$ from agricultural sources still dominates wet/bulk $\mathrm{N}$ deposi-
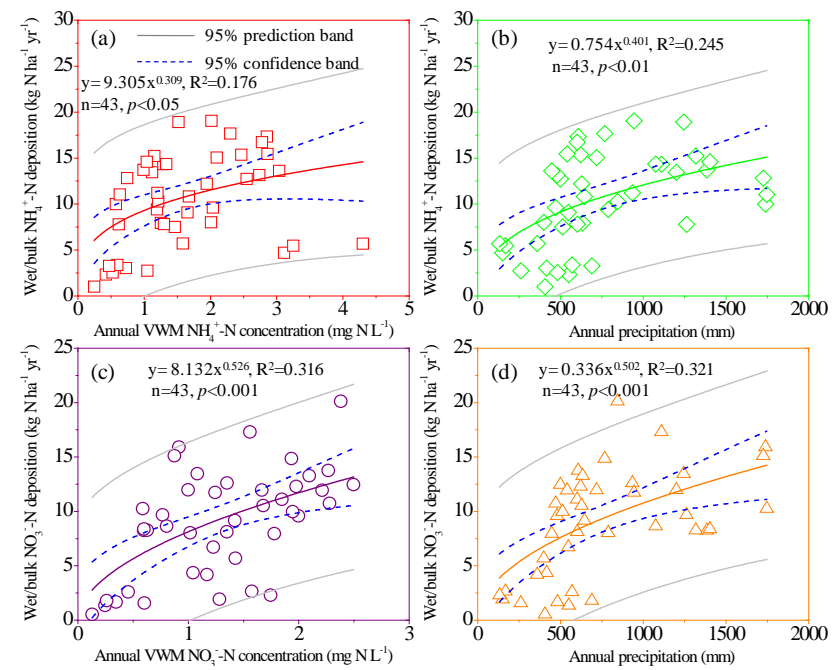

Figure 8. Correlations between annual wet/bulk $\mathrm{NH}_{4}^{+}-\mathrm{N}$ deposition and annual volume-weighted concentration of $\mathrm{NH}_{4}^{+}-\mathrm{N}$ (a) and annual precipitation (b); between annual wet/bulk $\mathrm{NO}_{3}^{-}-\mathrm{N}$ deposition and annual volume-weighted concentration of $\mathrm{NO}_{3}^{-}-\mathrm{N}$ (c) and annual precipitation $(\mathbf{d})$.

tion but the contribution has decreased drastically between the 1980s and the 2000s (Liu et al., 2013). Reduced N also contributed more than oxidized $\mathrm{N}$ to the total $\mathrm{N}$ deposition, and the ratio of reduced to oxidized $\mathrm{N}$ deposition overall averaged $1.6 \pm 0.7$ in dry deposition and $1.4 \pm 0.4$ in the total deposition (Fig. 5a, c).

The overall mean annual deposition fluxes (wet/bulk plus dry) of $\mathrm{NH}_{x}$ and $\mathrm{NO}_{y}$ for the period 2010-2014 was graded into five levels and plotted on maps showing the spatial distribution of $\mathrm{NH}_{3}$ and $\mathrm{NO}_{x}$ emissions (Fig. 9a, b). The anthropogenic emission data of $\mathrm{NH}_{3}$ and $\mathrm{NO}_{x}$ for the year 2010 

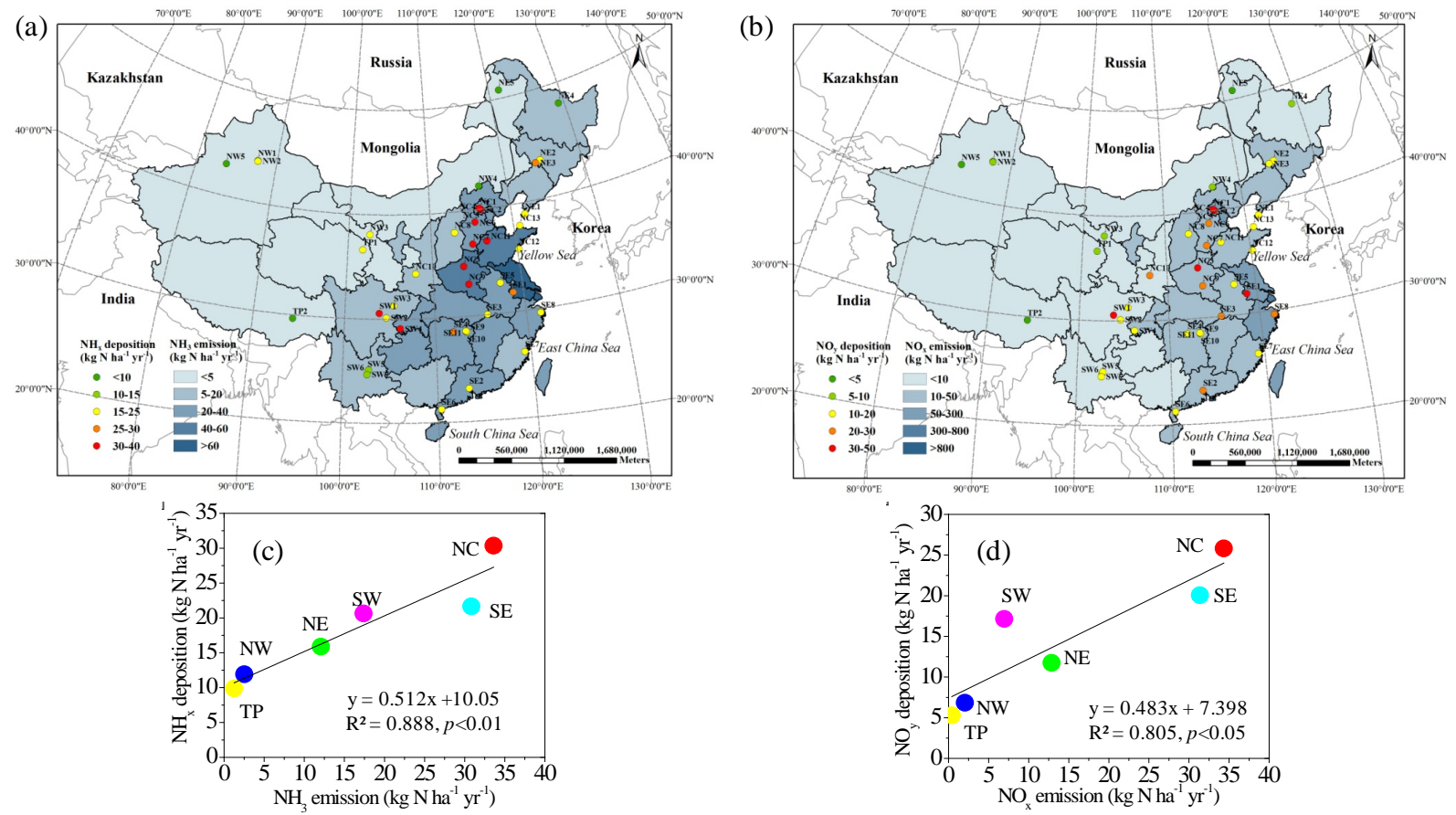

Figure 9. Spatial variation of atmospheric $\mathrm{N}$ deposition flux with emission distribution in China: (a) $\mathrm{NH}_{3}$ emission vs. $\mathrm{NH}_{x}$ deposition; (b) $\mathrm{NO}_{x}$ emission vs. $\mathrm{NO}_{y}$ deposition; (c) relationship of $\mathrm{NH}_{x}$ deposition vs. $\mathrm{NH}_{3}$ emission; (d) relationship of $\mathrm{NO}_{y}$ deposition vs. $\mathrm{NO}_{x}$ emission.

in China were obtained from the GAINS (Greenhouse Gas and Air Pollution Interactions and Synergies) model (http: //www.iiasa.ac.at/), and emission details for the 33 provinces of China are summarized in Table S5 of the Supplement. The spatial patterns of estimated $\mathrm{NH}_{x}$ and $\mathrm{NO}_{y}$ deposition compare reasonably well with the regional patterns of $\mathrm{NH}_{3}$ and $\mathrm{NO}_{x}$ emissions, respectively, even though the emission data were estimated at the province scale. With emission data, $\mathrm{N}$ deposition can be used to distinguish regional differences in reactive $\mathrm{N}_{\mathrm{r}}$ pollution. Across six regions, significantly positive correlations were found between $\mathrm{NH}_{3}$ emissions and $\mathrm{NH}_{x}$ deposition fluxes $\left(R^{2}=0.888, p<0.01\right)$ (Fig. 9c), and between $\mathrm{NO}_{x}$ emissions and $\mathrm{NO}_{y}$ deposition fluxes $\left(R^{2}=0.805, p<0.05\right)$ (Fig. 9d), implying that the $\mathrm{N}$ deposition fluxes to the six regions are strongly dependent on the spatial pattern of anthropogenic $\mathrm{N}_{\mathrm{r}}$ emissions within the regions. The slopes of the relationships of $\mathrm{NH}_{x}$ vs. $\mathrm{NH}_{3}$, and $\mathrm{NO}_{y}$ vs. $\mathrm{NO}_{x}$ were 0.51 and 0.48 , which could be roughly interpreted that $\mathrm{NH}_{x}$ and $\mathrm{NO}_{y}$ deposition fluxes represent about $51 \% \mathrm{NH}_{3}$ and $48 \% \mathrm{NO}_{x}$ emissions, respectively.

For all Chinese regions except NC, we cannot compare our data with other studies because observations for different pollution climate sites in other regions are lacking. For $\mathrm{NC}$, the overall average total $\mathrm{N}$ deposition was $56.2 \pm 14.8 \mathrm{~kg} \mathrm{Nha}^{-1} \mathrm{yr}^{-1}, 13-32 \%$ lower than the previously estimated values in northern China (Pan et al., 2012; Luo et al., 2013). This difference may reflect differences in the numbers of sampling sites, land use type, and as- sumed dry deposition velocities. As expected, our estimated deposition was substantially higher than the results of Lü and Tian (2007), who suggested that the total $\mathrm{N}$ deposition ranged from 13 to $20 \mathrm{~kg} \mathrm{~N} \mathrm{ha}^{-1} \mathrm{yr}^{-1}$ in NC. This is attributed to their omission of many major species (e.g., gaseous $\mathrm{NH}_{3}$, $\mathrm{HNO}_{3}$ and particulate $\mathrm{N}_{\mathrm{r}}$ ) from their data.

Compared to dry and wet $\mathrm{N}$ deposition fluxes estimated by CASTNET in the United States, EMEP in Europe, and EANET sites in Japan, the average values of dry and wet/bulk deposition in China are much higher (Table 1). In addition, on the basis of 2001 ensemble-mean modeling results from 21 global chemical transport models (Vet et al., 2014), three global N deposition hotspots were western Europe (with levels from 20.0 to $28.1 \mathrm{~kg} \mathrm{~N} \mathrm{ha}^{-1} \mathrm{yr}^{-1}$ ), South Asia (Pakistan, India, and Bangladesh) from 20.0 to $30.6 \mathrm{~kg} \mathrm{~N} \mathrm{ha}^{-1} \mathrm{yr}^{-1}$ and East Asia from 20 to $38.6 \mathrm{~kg} \mathrm{~N} \mathrm{ha}^{-1} \mathrm{yr}^{-1}$ in eastern China (the global maximum). Extensive areas of high deposition from 10 to $20 \mathrm{~kg} \mathrm{Nha}^{-1} \mathrm{yr}^{-1}$ appear in the eastern United States and southeastern Canada as well as most of central Europe. Small areas with total deposition of $\mathrm{N}$ from 10 to $20 \mathrm{~kg} \mathrm{Nha}^{-1} \mathrm{yr}^{-1}$ are present, and very large areas of the continents have deposition from 2 to $10 \mathrm{~kg} \mathrm{Nha}^{-1} \mathrm{yr}^{-1}$. In contrast, the present study shows a much higher total deposition flux (39.9 $\left.\mathrm{kg} \mathrm{N} \mathrm{ha}^{-1} \mathrm{yr}^{-1}\right)$ at a national scale. In China, the consumption rates of chemical fertilizer and fossil fuel have increased 2.0- and 3.2-fold, respectively, between the 1980s and the 2000s (Liu et al., 2013). As a result, the estimated total emission of $\mathrm{NH}_{3}$ reached $9.8 \mathrm{Tg}$ in 2006, con- 
Table 1. Comparison of dry, wet (wet/bulk), and total deposition fluxes of $\mathrm{N}_{\mathrm{r}}$ compounds between NNDMN in China and three networks in other countries.

\begin{tabular}{|c|c|c|c|c|c|c|c|c|c|c|c|c|c|}
\hline \multicolumn{2}{|l|}{ Network } & \multicolumn{3}{|c|}{ Japan EANET network ${ }^{\mathrm{a}}$} & \multicolumn{3}{|c|}{ CASTNET $^{b}$} & \multicolumn{3}{|c|}{ EMEP $^{\mathrm{c}}$} & \multicolumn{3}{|c|}{ NADMM $^{\mathrm{d}}$} \\
\hline Number of sites or grids & & \multicolumn{3}{|c|}{10 sites } & \multicolumn{3}{|c|}{130 sites } & \multicolumn{3}{|c|}{2447 girds $\left(0.5^{\circ} \times 0.5^{\circ}\right)$} & \multicolumn{3}{|c|}{33 sites } \\
\hline Observation period & & \multicolumn{3}{|c|}{ Apr 2003-Mar 2008} & \multicolumn{3}{|c|}{ Apr 2006-Dec 2013} & \multicolumn{3}{|c|}{ Jan 2003-Dec 2007} & \multicolumn{3}{|c|}{ Aug 2006-Sep 2014} \\
\hline \multirow[t]{5}{*}{$\mathrm{N}$ deposition $\left(\mathrm{kg} \mathrm{Nha}^{-1} \mathrm{yr}^{-1}\right)$} & & Dry & Wet & Total & Dry & Wet & Total & Dry & Wet & Total & Dry & Wet/bulk & Total \\
\hline & Average & 3.9 & 6.6 & 10.6 & 3.1 & 1.3 & 4.4 & 3.9 & 4.8 & 8.7 & 18.7 & 18.2 & 36.9 \\
\hline & Median & 4.1 & 5.9 & 11.2 & 3.0 & 0.7 & 4.1 & 3.7 & 4.7 & 8.5 & 18.7 & 21.3 & 36.5 \\
\hline & Max & 7.0 & 15.8 & 18.2 & 9.7 & 10.3 & 19.6 & 15.8 & 16.9 & 28.0 & 43.1 & 32.4 & 70.9 \\
\hline & Min & 1.0 & 2.1 & 3.0 & 0.03 & 0.1 & 0.3 & 0.1 & 0.6 & 0.7 & 1.1 & 1.5 & 2.9 \\
\hline
\end{tabular}

a The Japan EANET data are sourced from Endo et al. (2011). Gaseous $\mathrm{NO}_{2}$ was not included in estimates of dry N deposition. ${ }^{\mathrm{b}}$ The CASNET data are available online (http://www.epa.gov/castnet/). Gaseous $\mathrm{NH}_{3}$ was not included in estimates of dry $\mathrm{N}$ deposition. ${ }^{\mathrm{c}}$ The EMEP data are sourced from Endo et al. (2011), in which the dry and wet deposition amounts at each grid covering 27 EMEP countries were estimated by the unified EMEP models (Simpson et al., 2003). ${ }^{\mathrm{d}}$ Only including the rural and background sites in NNDMN.

tributing approximately 15 and $35 \%$ to the global and Asian $\mathrm{NH}_{3}$ emissions (Huang et al., 2012). $\mathrm{NO}_{x}$ emissions from fossil fuel combustion increased from $1.1 \mathrm{Tg} \mathrm{N}$ in 1980 to about 6.0 Tg N in 2010 (Liu et al., 2013). The increasing $\mathrm{NO}_{x}$ and $\mathrm{NH}_{3}$ emissions in China led to higher atmospheric $\mathrm{N}$ deposition than those observed in other regions.

According to Endo et al. (2011), the low dry deposition fluxes in CASTNET, EMEP, and Japan's EANET network are due at least partly to low concentrations of $\mathrm{N}_{\mathrm{r}}$ compounds and/or the omission of dry deposition fluxes of major $\mathrm{N}_{\mathrm{r}}$ species (e.g., $\mathrm{NO}_{2}$ and $\mathrm{NH}_{3}$ ) from the data. Meanwhile, the low wet deposition fluxes at these networks are likely to be a result of the combined effects of low amounts of precipitation and, especially, low atmospheric $\mathrm{N}_{\mathrm{r}}$ concentrations. In addition, emissions of nitrogen compounds in other parts of the world are declining. In the United States, for example, $\mathrm{NO}_{x}$ emissions from the power sector and mobile sources were reduced by half from 1990 to 2010 (Xing et al., 2013), which explained the declined $\mathrm{N}$ deposition fluxes during the period of 1990-2009 observed at 34 paired dry and wet monitoring sites in the eastern United States (Sickles II and Shadwick, 2015). In Europe, the total $\mathrm{NO}_{x}$ and $\mathrm{NH}_{3}$ emissions decreased by 31 and $29 \%$ from 1990 to 2009 (Tørseth et al., 2012). N deposition has decreased or stabilized in the United States and Europe since the late 1980s or early 1990s with the implementation of stricter legislation to reduce emissions (Goulding et al., 1998; Holland et al., 2005). However, wet deposition of ammonia or ammonium, which is not regulated, has increased over recent decades in the United States (Du et al., 2014).

\subsection{Implications of monitoring $\mathrm{N}_{\mathrm{r}}$ concentration and deposition on regional $\mathbf{N}$ deposition simulation}

Our results show that atmospheric concentrations and deposition of $\mathrm{N}_{\mathrm{r}}$ in China were high in the 2000s, although the government has made considerable efforts to control environmental pollution by improving air quality in mega cities during and after the 2008 Beijing Summer Olympic Games (Wang et al., 2010; Chan and Yao, 2008). Ideally, the spatial distribution of monitoring sites should reflect the gradients in the concentrations and deposition fluxes of atmospheric $\mathrm{N}_{r}$ species. Given the fact that the arithmetic averages used in this study cannot give a completely accurate evaluation of $\mathrm{N}_{\mathrm{r}}$ levels for the regions of China due to the limited numbers of monitoring sites and land use types, it is important to develop and improve the quantitative methods for determining $\mathrm{N}$ deposition across China.

Numerical models are very useful tools to quantify atmospheric $\mathrm{N}$ deposition (including both spatial and temporal variations), but a challenge to the modeling approaches is that observations to validate the simulated concentrations and deposition fluxes are often lacking. In our study 43 monitoring sites were selected in a range of land use types to provide more representative regional information on $\mathrm{N}$ deposition in China. Although those measurements cannot define all aspects of $\mathrm{N}$ deposition across different regions, they add substantially to existing knowledge concerning the spatial patterns and magnitudes of $\mathrm{N}$ deposition. The present measurements will be useful for better constraining emission inventories and evaluating simulations from atmospheric chemistry models. In future studies we will use models (e.g., FRAME, Dore et al., 2012) integrated with measurements from our monitoring network to fully address the spatial-temporal variations of atmospheric $\mathrm{N}$ deposition and its impacts on natural and semi-natural ecosystems at the regional/national level.

\subsection{Uncertainty analysis of the $\mathrm{N}$ dry and wet deposition fluxes}

The dry deposition fluxes were estimated by combining measured concentrations with modeled $V_{\mathrm{d}}$. As summarized in Table $\mathrm{S} 4$, our estimates of dry deposition velocities for different $\mathrm{N}_{\mathrm{r}}$ species are generally consistent with previous studies (e.g., Flechard et al., 2011; Pan et al., 2012). Some uncertainties may still exist in the inputs for dry deposition modeling. For example, underlying surface parameters (e.g., surface roughness length and land type) strongly affect dry deposition through their effect on both deposition velocity 
and the absorbability of the ground surface to each of the gaseous and particulate $\mathrm{N}_{\mathrm{r}}$ species (Loubet et al., 2008). In addition, there is uncertainty in the deposition fluxes for both $p \mathrm{NH}_{4}^{+}$and $p \mathrm{NO}_{3}^{-}$in our network, resulting from the difference between the cut-off sizes of particles in the samplers and those defined in the modeled $V_{\mathrm{d}}$, which was calculated for atmospheric $\mathrm{PM}_{2.5}$ in GEOS-Chem model. For example, the cut-off sizes of the samples can also collect coarse $\mathrm{NO}_{3}^{-}$ particles (e.g., calcium nitrate) but should have little effect on $\mathrm{NH}_{4}^{+}$particles (mainly in the fine scale $<1 \mu \mathrm{m}$ ) (Tang et al., 2009), resulting in an underestimation of $\mathrm{pNO}_{3}^{-}$deposition. Furthermore, $\mathrm{NH}_{3}$ fluxes over vegetated land are bi-directional and the net direction of this flux is often uncertain. A so-called canopy compensation point was used in previous studies (Sutton et al., 1998) to determine the direction of the $\mathrm{NH}_{3}$ flux. Since the principle of bi-directional $\mathrm{NH}_{3}$ exchange was not considered in this study, $\mathrm{NH}_{3}$ deposition may be overestimated at rural sites with relatively high canopy compensation points (e.g., up to $5 \mu \mathrm{g} \mathrm{N} \mathrm{m}^{-3}$ ) due to fertilized croplands or vegetation (Sutton et al., 1993).

On the other hand, the total dry deposition flux in this study may be underestimated due to omission of the drydeposited organic $\mathrm{N}$ species in our network and missing $\mathrm{HNO}_{3}$ data at very few sites as noted earlier (see Sect. 2.2). Organic $N$ species have been found to make an important contribution to the $\mathrm{N}$ dry deposition. For example, PAN accounted for $20 \%$ of the daytime, summertime $\mathrm{NO}_{y}\left(\mathrm{NO}+\mathrm{NO}_{2}+\mathrm{HNO}_{3}+\mathrm{NO}_{3}^{-}+\mathrm{PAN}\right)$ dry deposition at a coniferous forest site (Turnipseed et al., 2006). However, the contribution of PAN and other known atmospheric organic nitrates to total $\mathrm{N}_{\mathrm{r}}$ inputs must be minor on an annual timescale, as reported by Flechard et al. (2012). In previous work, dry deposition flux was inferred from atmospheric $\mathrm{N}_{\mathrm{r}}$ concentrations and a literature-based annual mean deposition velocity (Shen et al., 2009), or reported by Luo et al. (2013), who did not consider the different dry deposition velocities of various $\mathrm{N}_{\mathrm{r}}$ species among different land use types. Clearly, in this study we have greatly improved the estimation of dry deposition, but further work is still required to increase the reliability and accuracy of $\mathrm{N}$ dry deposition values.

Since wet/bulk deposition was measured directly, the reported fluxes are considered more accurate than dry deposition fluxes but still some uncertainties exist. On one hand, the estimated fluxes obtained from the open precipitation samplers contain contributions from wet plus unquantifiable dry deposition (including both gases and particles) and therefore likely overestimate actual wet deposition (Cape et al., 2009; Liu et al., 2015). For example, our previous research showed that annual unquantifiable dry deposition (the difference between bulk and wet deposition, approx. $6 \mathrm{~kg} \mathrm{Nha}^{-1}$ on average) accounted for $20 \%$ of bulk $\mathrm{N}$ deposition based on observations at three rural sites on the North China Plain (Y. Zhang et al., 2008). This contribution increased to $39 \%$ in urban areas based on a recent measurement (Zhang et al., 2015). On the other hand, dissolved organic $\mathrm{N}$ compounds, which have been observed to contribute around $25-30 \%$ of the total dissolved nitrogen in wet deposition around the world (Jickells et al., 2013) and approximately $28 \%$ of the total atmosphere bulk $\mathrm{N}$ deposition in China (Y. Zhang et al., 2012), were not considered in the present study. Their exclusion here would contribute to an underestimation of the total wet $\mathrm{N}$ deposition.

Although the NNDMN is the only long-term national deposition network to monitor both $\mathrm{N}$ wet/bulk and dry deposition in China till now, large areas of the country and islands do not contain sampling points, which may result in missing hotspots or pristine sites of $\mathrm{N}$ deposition. The implementation of an adequate monitoring program is also difficult at present in some regions (e.g., northwest China and the Tibetan Plateau). To address this issue, more new monitoring sites, covering regions with both extremely low and high $\mathrm{N}_{\mathrm{r}}$ emissions, should be set up in the NNDMN in future work.

\section{Conclusions}

In this paper, we systematically reported large spatial variations in annual mean concentrations (1.3$\left.47.0 \mu \mathrm{g} \mathrm{N} \mathrm{m}^{-3}\right)$, dry $\left(1.1\right.$ to $\left.52.2 \mathrm{~kg} \mathrm{Nha}^{-1} \mathrm{yr}^{-1}\right)$, wet/bulk (1.5-32.5 $\left.\mathrm{kg} \mathrm{Nha}^{-1} \mathrm{yr}^{-1}\right)$ and total (2.9 to $83.3 \mathrm{~kg} \mathrm{Nha}^{-1} \mathrm{yr}^{-1}$ ) deposition fluxes of atmospheric $\mathrm{N}_{\mathrm{r}}$ species across the 43 monitoring sites in China. On a regional/national basis, the annual mean concentrations and deposition fluxes of $\mathrm{N}_{\mathrm{r}}$ species ranked by the same order of urban $>$ rural $>$ background sites and $\mathrm{NC}>\mathrm{SE}>\mathrm{SW}>\mathrm{NE}>\mathrm{NW}>\mathrm{TP}$, reflecting the impact of varying anthropogenic $\mathrm{N}_{\mathrm{r}}$ emissions in different land use types and/or regions.

Dry deposition fluxes of $\mathrm{N}_{\mathrm{r}}$ species on average contributed $52 \%$ of the total $\mathrm{N}$ deposition $\left(39.9 \mathrm{~kg} \mathrm{Nha}^{-1} \mathrm{yr}^{-1}\right.$ ) across all sites, indicating the importance of dry deposition monitoring for a complete $\mathrm{N}$ deposition assessment at the national scale. Annual average ratios of reduced $\mathrm{N} /$ oxidized $\mathrm{N}$ in dry, wet/bulk and total deposition were 1.6, 1.3, and 1.4, respectively, suggesting that reduced $\mathrm{N}$, mainly from agricultural sources, still dominates dry, wet/bulk, and total $\mathrm{N}$ deposition in China.

Our work represents the first effort to investigate both dry and wet/bulk $\mathrm{N}$ deposition simultaneously, based on a nationwide monitoring network in China. We consider this unique data set important for not only informing policymakers about the abatement of pollutant emissions and ecosystem protection but also validating model estimations of $\mathrm{N}$ deposition at the regional/national scale. For better understanding atmospheric $\mathrm{N}$ deposition fluxes in China, further studies in the future are still required at least the two following aspects: (1) to cover more representative monitoring sites, and (2) to improve the dry deposition velocity estimates of vari- 
ous $\mathrm{N}_{\mathrm{r}}$ species using a single-point dry deposition model as for CASTNET.

\section{The Supplement related to this article is available online at doi:10.5194/acp-15-12345-2015-supplement.}

Acknowledgements. This study was supported by the Chinese National Basic Research Program (2014CB954202), the China Funds for Distinguished Young Scholars of NSFC (40425007), and the National Natural Science Foundation of China (31121062, 41321064 and 41405144). The authors thank all technicians at monitoring sites in NNDMN, and W. Aas and two anonymous reviewers for their constructive suggestions on the manuscript.

Edited by: L. Zhang

\section{References}

Bey, I., Jacob, D. J., Yantosca, R. M., Logan, J. A., Field, B. D., Fiore, A. M., Li, Q., Liu, H., Mickley, L. J., and Schultz, M. G.: Global modeling of tropospheric chemistry with assimilated meteorology: Model description and evaluation, J. Geophys. Res., 106, 23073-23096, 2001.

Behera, S. N., Sharma, M., Aneja, V. P., and Balasubramanian, R.: Ammonia in the atmosphere: a review on emission sources, atmospheric chemistry and deposition on terrestrial bodies, Environ. Sci. Pollut. R., 20, 8092-8131, doi:10.1007/s11356-0132051-9, 2013.

Cape, J. N., Van Dijk, N., and Tang, Y. S.: Measurement of dry deposition to bulk collectors using a novel flushing sampler, J. Environ. Monitor., 11, 353-358, doi:10.1039/B813812E, 2009.

Chan, C. K. and Yao, X. H.: Air pollution in mega cities in China, Atmos. Environ., 42, 1-42, doi:10.1016/j.atmosenv.2007.09.003, 2008.

Chen, D., Wang, Y., McElroy, M. B., He, K., Yantosca, R. M., and Le Sager, P.: Regional CO pollution and export in China simulated by the high-resolution nested-grid GEOS-Chem model, Atmos. Chem. Phys., 9, 3825-3839, doi:10.5194/acp-9-3825-2009, 2009.

Chen, X. Y. and Mulder, J.: Atmospheric deposition of nitrogen at five subtropical forested sites in South China, Sci. Total Environ., 378, 317-330, doi:10.1016/j.scitotenv.2007.02.028, 2007.

Clark, C. M. and Tilman, D.: Loss of plant species after chronic low-level nitrogen deposition to prairie grasslands, Nature, 451, 712-715, doi:10.1038/nature06503, 2008.

Clarke, J. F., Edgerton, E. S., and Martin, B. E.: Dry deposition calculations for the Clean Air Status and Trends Network, Atmos. Environ., 31, 3667-3678, 1997.

CSY: China Statistical Yearbook, available at: http://www.stats.gov. cn (last access: 23 September 2015), 2007-2014.

Cui, J., Zhou, J., Peng, Y., He, Y. Q., Yang, H., Mao, J. D., Zhang, M. L., Wang, Y. H., and Wang, S. W.: Atmospheric wet deposition of nitrogen and sulfur in the agroecosystem in developing and developed areas of Southeastern China, Atmos. Environ., 89, 102-108, doi:10.1016/j.atmosenv.2014.02.007, 2014.
Dentener, F., Drevet, J., Lamarque, J. F., Bey, L., Eickhout, B., Fiore, A. M. Hauglustaine, D., Horowitz, L. W., Krol, M., and Kulshrestha, U. C.: Nitrogen and sulfur deposition on regional and global scales: a multimodel evaluation, Global Biogeochem. Cy., 20, GB4003, doi:10.1029/2005GB002672, 2006.

Dore, A. J., Kryza, M., Hall, J. R., Hallsworth, S., Keller, V. J. D., Vieno, M., and Sutton, M. A.: The influence of model grid resolution on estimation of national scale nitrogen deposition and exceedance of critical loads, Biogeosciences, 9, 1597-1609, doi:10.5194/bg-9-1597-2012, 2012.

Du, E. Z., Vries, W. D., Galloway, J. N., Hu, X. Y., and Fang, J. Y.: Changes in wet nitrogen deposition in the United States between 1985 and 2012, Environ. Res. Lett., 9, 095004, doi:10.1088/1748-9326/9/9/095004, 2014.

EEA: Air Quality in Europe-2011 Report, Technical Report 12/2011, EEA, Kopenhagen, 2011.

Ellis, R. A., Jacob, D. J., Sulprizio, M. P., Zhang, L., Holmes, C. D., Schichtel, B. A., Blett, T., Porter, E., Pardo, L. H., and Lynch, J. A.: Present and future nitrogen deposition to national parks in the United States: critical load exceedances, Atmos. Chem. Phys., 13, 9083-9095, doi:10.5194/acp-13-9083-2013, 2013.

Endo, T., Yagoh, H., Sato, K., Matsuda, K., Hayashi, K., Noguchi, I., and Sawada, K.: Regional characteristics of dry deposition of sulfur and nitrogen compounds at EANET sites in Japan from 2003 to 2008, Atmos. Environ., 45, 1259-1267, doi:10.1016/j.atmosenv.2010.12.003, 2011.

Erisman, J. W., Vermeulen, A., Hensen, A., Flechard, C., Dammgen, U., Fowler, D., Sutton, M., Grunhage, L., and Tuovinen, J. P.: Monitoring and modelling of biosphere/atmosphere exchange of gases and aerosols in Europe, Environ. Pollut., 133, 403-413, doi:10.1016/j.envpol.2004.07.004, 2005.

Flechard, C. R., Nemitz, E., Smith, R. I., Fowler, D., Vermeulen, A. T., Bleeker, A., Erisman, J. W., Simpson, D., Zhang, L., Tang, Y. S., and Sutton, M. A.: Dry deposition of reactive nitrogen to European ecosystems: a comparison of inferential models across the NitroEurope network, Atmos. Chem. Phys., 11, 2703-2728, doi:10.5194/acp-11-2703-2011, 2011.

Fowler, D., Coyle, M., Skiba, U., Sutton, M. A., Cape, J. N., Reis, S., Sheppard, L. J., Jenkins, A., Grizzetti, B., Galloway, J. N., Vitousek, P., Leach, A., Bouwman, A. F., Butterbach-Bahl, K., Dentener, F., Stevenson, D., Amann, M., and Voss, M.: The global nitrogen cycle in the twenty-first century, Philos. T. R. Soc. B, 368, 20130164, doi:10.1098/rstb.2013.0164, 2013.

Galloway, J. N., Dentener, F. J., Capone, D. G., Boyer, E. W., Howarth, R. W., Seitzinger, S. P., Asner, G. P., Cleveland, C. C., Green, P. A., Holland, E. A., Karl, D. M., Michaels, A. F., Porter, J. H., Townsend, A. R., and Vorosmarty, C. J.: Nitrogen cycles: past, present, and future, Biogeochem., 70, 153-226, 2004.

Galloway, J. N., Townsend, A. R., Erisman, J. W., Bekunda, M., Cai, Z., Freney, J. R., Martinelli, L. A., Seitzinger, S. P., and Sutton, M. A.: Transformation of the Nitrogen Cycle: Recent trends, questions, and potential solutions, Science, 320, 889-892, 2008.

Galloway, J. N., Leach, A. M., Bleeker, A., and Erisman, J. W.: A chronology of human understanding of the nitrogen cycle, Philos. T. R. Soc. B, 368, 20130120, doi:10.1098/rstb.2013.0120, 2013.

Goulding, K. W. T., Bailey, N. J., Bradbury, N. J., Hargreaves, P., Howe, M., Murphy, D. V., Poulton, P. R., and Willison, T. W.: 
Nitrogen deposition and its contribution to nitrogen cycling and associated soil processes, New Phytol., 139, 49-58, 1998.

Gu, B. J., Ge, Y., Ren, Y., Xu, B., Luo, W. D., Jiang, H., Gu, B. H., and Chang, J.: Atmospheric reactive nitrogen in China: Sources, recent trends, and damage costs, Environ. Sci. Technol., 46, 9240-9247, doi:10.1021/es301446g, 2012.

Gu, B. J., Sutton, M. A., Chang, S. X., Ge, Y., and Jie, C.: Agricultural ammonia emissions contribute to China's urban air pollution, Front. Ecol. Environ., 12, 265-266, doi:10.1890/14.WB.007, 2014.

Holland, E. A., Braswell, B. H., Sulzman, J., and Lamarque, J. F.: Nitrogen deposition onto the United States and Western Europe: synthesis of observations and models, Ecol. Appl., 15, 38-57, 2005.

Hu, H., Yang, Q., Lu, X., Wang, W., Wang, S., and Fan, M.: Air pollution and control in different areas of China, Crit. Rev. Env. Sci. Tec., 40, 452-518, doi:10.1080/10643380802451946, 2010.

Huang, X., Song, Y., Li, M. M., Li, J. F., Huo, Q., Cai, X. H., Zhu, T., Hu, M., and Zhang, H. S.: A high-resolution ammonia emission inventory in China, Global Biogeochem. Cy., 26, GB1030, doi:10.1029/2011GB004161, 2012.

Huang, Y. L., Lu, X. X., and Chen, K.: Wet atmospheric deposition of nitrogen: 20 years measurement in Shenzhen City, China, Environ. Monit. Assess., 185, 113-122, doi:10.1007/s10661-0122537-9, 2013

Jia, Y. L., Yu, G. R., He, N. P., Zhan, X. Y., Fang, H. J., Sheng, W. P., Zuo, Y., Zhang, D. Y., and Wang, Q. F.: Spatial and decadal variations in inorganic nitrogen wet deposition in China induced by human activity, Sci. Rep., 4, 3763, doi:10.1038/srep03763, 2014.

Jickells, T., Baker, A. R., Cape, J. N., Cornell, S. E., and Nemitz, E.: The cycling of organic nitrogen through the atmosphere, Philos. T. R. Soc. B, 368, 20130115, doi:10.1098/rstb.2013.0115, 2013.

Li, Y. E. and Lin, E. D.: Emissions of $\mathrm{N}_{2} \mathrm{O}, \mathrm{NH}_{3}$ and $\mathrm{NO}_{x}$ from fuel combustion, industrial processes and the agricultural sectors in China, Nutr. Cycl. Agroecosys., 57, 99-106, 2000.

Liu, X. J., Song, L., He, C. E., and Zhang, F. S.: Nitrogen deposition as an important nutrient from the environment and its impact on ecosystems in China, J. Arid Land, 2, 137-143, 2010.

Liu, X. J., Duan, L., Mo, J. M., Du, E., Shen, J. L., Lu, X. K., Zhang, Y., Zhou, X. B., He, C. E., and Zhang, F. S.: Nitrogen deposition and its ecological impact in China: An overview, Environ. Pollut., 159, 2251-2264, doi:10.1016/j.envpol.2010.08.002, 2011.

Liu, X. J., Zhang, Y., Han, W. X., Tang, A., Shen, J. L., Cui, Z. L., Vitousek, P., Erisman, J. W., Goulding, K., Christie, P., Fangmeier, A., and Zhang, F. S.: Enhanced nitrogen deposition over China, Nature, 494, 459-462, doi:10.1038/nature11917, 2013.

Liu, X. J., Xu, W., Pan, Y. P., and Du, E. Z.: Liu et al. suspect that Zhu et al. (2015) may have underestimated dissolved organic nitrogen $(\mathrm{N})$ but overestimated total particulate $\mathrm{N}$ in wet deposition in China, Sci. Total Environ., 520, 300-301, doi:10.1016/j.scitotenv.2015.03.004, 2015.

Loubet, B., Asman, W. A. H., Theobald, M. R., Hertel, O., Tang, S. Y., Robin, P., Hassouna, M., Dämmgen, U., Genermont, S., Cellier, P., and Sutton, M. A.: Ammonia deposition near hot spots: processes, models and monitoring methods, in: Atmospheric ammonia: detecting emission changes and environmental impacts, edited by: Sutton, M. A., Reis, S., and Baker, S. M. H., Netherlands, Springer, 205-251, 2008.
Lü, C. Q. and Tian, H. Q.: Spatial and temporal patterns of nitrogen deposition in China: Synthesis of observational data, J. Geophys. Res., 112, D22S05, doi:10.1029/2006JD007990, 2007.

Lü, C. Q. and Tian, H. Q.: Half-century nitrogen deposition increase across China: A gridded time-series data set for regional environmental assessments, Atmos. Environ., 97, 68-74, 2014.

Luo, X. S., Liu, P., Tang, A. H., Liu, J. Y., Zong, X. Y., Zhang, Q., Kou, C. L., Zhang, L. J., Fowler, D., Fangmeier, A., Christie, P., Zhang, F. S., and Liu, X. J.: An evaluation of atmospheric $\mathrm{Nr}$ pollution and deposition in North China after the Beijing Olympics, Atmos. Environ., 74, 209-216, doi:10.1016/j.atmosenv.2013.03.054, 2013.

Maston, P., Lohse, K. A., and Hall, S. J.: The globalization of nitrogen deposition: Consequences for terrestrial ecosystems, Ambio, 31, 113-119, 2002.

MEPC (Ministry of Environmental Protection of the People's Republic of China): China's environment and data center, available at: www.zhb.gov.cn/ (last access: 23 April 2014), 2014.

Pan, Y. P., Wang, Y. S., Tang, G. Q., and Wu, D.: Wet and dry deposition of atmospheric nitrogen at ten sites in Northern China, Atmos. Chem. Phys., 12, 6515-6535, doi:10.5194/acp-12-65152012, 2012.

Reche, C., Viana, M., Pandolfi, M., Alastuey, A., Moreno, T., Amato, F., Ripoll, A., and Querol, X.: Urban $\mathrm{NH}_{3}$ levels and sources in a Mediterranean environment, Atmos. Environ., 57, 153-164, doi:10.1016/j.atmosenv.2012.04.021, 2012.

Richter, D. D., Burrows, J. P., Nüß, H., Granier, C., and Niemeier, U.: Increase in tropospheric nitrogen dioxide over China observed from space, Nature, 437, 129-132, 2005.

Schwede, D., Zhang, L., Vet, R., and Lear, G.: An intercomparison of the deposition models used in the CASTNET and CAPMoN networks, Atmos. Environ., 45, 1337-1346, doi:10.1016/j.atmosenv.2010.11.050, 2011.

Seinfeld, J. and Pandis, S.: Atmospheric Chemistry and Physics: From Air Pollution to Climate Change, John Wiley and Sons, 2nd Edn., 1203 pp., 2006.

Shen, J. L., Tang, A. H., Liu, X. J., Fangmeier, A., Goulding, K. T. W., and Zhang, F. S.: High concentrations and dry deposition of reactive nitrogen species at two sites in the North China Plain, Environ. Pollut., 157, 3106-3113, doi:10.1016/j.envpol.2009.05.016, 2009.

Sickles II, J. E. and Shadwick, D. S.: Air quality and atmospheric deposition in the eastern US: 20 years of change, Atmos. Chem. Phys., 15, 173-197, doi:10.5194/acp-15-173-2015, 2015.

Simpson, D., Fagerli, H., Jonson, J. E., Tsyro, S., Wind, P., and Tuovinen, J. P.: Trans-boundary Acidification and Eutrophication and Ground Level Ozone in Europe: Unified EMEP Model Description, EMEP Status Report 1/2003 Part I, EMEP/MSC-W Report, The Norwegian Meteorological Institute, Oslo, Norway, 2003.

Skeffington, R. A. and Hill, T. J.: The effects of a changing pollution climate on throughfall deposition and cycling in a forested area in southern England, Sci. Total Environ., 434, 28 38, doi:10.1016/j.scitotenv.2011.12.038, 2012.

Sutton, M. A., Pitcairn, C. E. R., and Fowler, D.: The exchange of ammonia between the atmosphere and plant communities, Adv. Ecol. Res., 24, 301-393, doi:10.1016/S0065-2504(08)60045-8, 1993. 
Sutton, M. A., Burkhardt, J. K., Guerin, D., Nemitz, E., and Fowler, D.: Development of resistance models to describe measurements of bi-directional ammonia surface-atmosphere exchange, Atmos. Environ., 32, 473-480, doi:10.1016/S1352-2310(97)00164-7, 1998.

Sutton, M. A., Tang, Y. S., Miners, B., and Fowler, D.: A new diffusion denuder system for long-term, regional monitoring of atmospheric ammonia and ammonium, Water Air Soil Poll. Focus, 1, 145-156, 2001.

Tang, Y. S., Simmons, I., van Dijk, N., Di Marco, C., Nemitz, E., Dammgen, U., Gilke, K., Djuricic, V., Vidic, S., and Gliha, Z.: European scale application of atmospheric reactive nitrogen measurements in a low-cost approach to infer dry deposition fluxes, Agr. Ecosyst. Environ., 133, 183-195, doi:10.1016/j.agee.2009.04.027, 2009.

Tørseth, K., Aas, W., Breivik, K., Fjæraa, A. M., Fiebig, M., Hjellbrekke, A. G., Lund Myhre, C., Solberg, S., and Yttri, K. E.: Introduction to the European Monitoring and Evaluation Programme (EMEP) and observed atmospheric composition change during 1972-2009, Atmos. Chem. Phys., 12, 5447-5481, doi:10.5194/acp-12-5447-2012, 2012.

Turnipseed, A. A., Huey, L. G., Nemitz, E., Stickel, R., Higgs, J., Tanner, D. J., Slusher, D. L., Sparks, J. P., Flocke, F., and Guenther, A.: Eddy covariance fluxes of peroxyacetyl nitrates (PANs) and $\mathrm{NO}_{y}$ to a coniferous forest, J. Geophys. Res., 111, D09304, doi:10.1029/2005JD006631, 2006.

Vet, R., Artz, R. S., Carou, S., Shaw, M., Ro, C.-U., Aas, W., Baker, A., Bowersox, V. C., Dentener, F., Galy-Lacaux, C., Hou, A., Pienaar, J. J., Gillett, R., Forti, M. C., Gromov, S., Hara, H., Khodzher, T., Mahowald, N. M., Nickovic, S., Rao, P. S. P., and Reid, N. W.: A global assessment of precipitation chemistry and deposition of sulfur, nitrogen, sea salt, base cations, organic acids, acidity and $\mathrm{pH}$, and phosphorus, Atmos. Environ., 93, 3100, doi:10.1016/j.atmosenv.2013.10.060, 2014.

Vitousek, P. M., Aber, J. D., Howarth, R. W., Likens, G. E., Matson, P. A., Schindler, D. W., Schlesinger, W. H., and Tilman, D. G.: Human alteration of the global nitrogen cycle: Sources and consequences, Ecol. Appl., 7, 737-750, 1997.

Wang, S. X., Xing, J., Zhao, B., Jang, C., and Hao, J. M.: Effectiveness of national air pollution control policies on the air quality in metropolitan areas of China, J. Environ. Sci., 26, 13-22, doi:10.1016/S1001-0742(13)60381-2, 2014.

Wang, T., Nie, W., Gao, J., Xue, L. K., Gao, X. M., Wang, X. F., Qiu, J., Poon, C. N., Meinardi, S., Blake, D., Wang, S. L., Ding, A. J., Chai, F. H., Zhang, Q. Z., and Wang, W. X.: Air quality during the 2008 Beijing Olympics: secondary pollutants and regional impact, Atmos. Chem. Phys., 10, 7603-7615, doi:10.5194/acp10-7603-2010, 2010.

Wesely, M. L.: Parameterization of surface resistances to gaseous dry deposition in regional-scale numerical-models, Atmos. Environ., 23, 1293-1304, 1989.

Xing, J., Pleim, J., Mathur, R., Pouliot, G., Hogrefe, C., Gan, C.-M., and Wei, C.: Historical gaseous and primary aerosol emissions in the United States from 1990 to 2010, Atmos. Chem. Phys., 13, 7531-7549, doi:10.5194/acp-13-7531-2013, 2013.
Yu, W. T., Jiang, C. M., Ma, Q., Xu, Y. G., Zou, H., and Zhang, S. C.: Observation of the nitrogen deposition in the lower Liaohe River Plain, Northeast China and assessing its ecological risk, Atmos. Res., 101, 460-468, doi:10.1016/j.atmosres.2011.04.011, 2011.

Zhan, X., Yu, G., He, N., Jia, B., Zhou, M., Wang, C., Zhang, J., Zhao, G., Wang, S., Liu, Y., and Yan, J.: Inorganic nitrogen wet deposition: Evidence from the NorthSouth Transect of Eastern China, Environ. Pollut., 204, 1-8, doi:10.1016/j.envpol.2015.03.016, 2015.

Zhang, F. S., Wang, J. Q., Zhang, W. F., Cui, Z. L., Ma, W. Q., Chen, X. P., and Jiang, R. F.: Nutrient use efficiency of major cereal crops in China and measures for improvement, Acta. Pedologia Sinica, 45, 915-924, 2008 (in Chinese with English abstract).

Zhang, G. Z., Pan, Y. P., Tian, S. L., Cheng, M. T., Xie, Y. Z., Wang, H., and Wang, Y. S.: Limitations of passive sampling technique of rainfall chemistry and wet deposition flux characterization, Res. Environ. Sci., 28, 684-690, doi:10.13198/j.issn.10016929.2015.05.03, 2015.

Zhang, L., Jacob, D. J., Knipping, E. M., Kumar, N., Munger, J. W., Carouge, C. C., van Donkelaar, A., Wang, Y. X., and Chen, D.: Nitrogen deposition to the United States: distribution, sources, and processes, Atmos. Chem. Phys., 12, 4539-4554, doi:10.5194/acp-12-4539-2012, 2012.

Zhang, L. M., Gong, S. L., Padro, J., and Barrie, L.: A size-segregated particle dry deposition scheme for an atmospheric aerosol module, Atmos. Environ., 35, 549-560, doi:10.1016/s1352-2310(00)00326-5, 2001.

Zhang, Y., Liu, X. J., Fangmeier, A., Goulding, K. T. W., and Zhang, F. S.: Nitrogen inputs and isotopes in precipitation in the North China Plain, Atmos. Environ., 42, 1436-1448, doi:10.1016/j.atmosenv.2007.11.002, 2008.

Zhang, Y., Dore, A. J., Ma, L., Liu, X. J., Ma, W. Q., Cape, J. N., and Zhang, F. S.: Agricultural ammonia emissions inventory and spatial distribution in the North China Plain, Environ. Pollut., 158, 490-501, doi:10.1016/j.envpol.2009.08.033, 2010.

Zhang, Y., Song, L., Liu, X. J., Li, W. Q., Lü, S. H., Zheng, L. X., Bai, Z. C., Cui, G. Y., and Zhang, F. S.: Atmospheric organic nitrogen deposition in China, Atmos. Environ., 46, 195204, doi:10.1016/j.atmosenv.2011.09.080, 2012.

Zhao, Y., Zhang, L., Pan, Y., Wang, Y., Paulot, F., and Henze, D. K.: Atmospheric nitrogen deposition to the northwestern Pacific: seasonal variation and source attribution, Atmos. Chem. Phys., 15, 10905-10924, doi:10.5194/acp-15-10905-2015, 2015.

Zhu, J. X., He, N. P., Wang, Q. F., Yan, G. F., Wen, D., Yu, G. R., and Jia, Y. L.: The composition, spatial patterns, and influencing factors of atmospheric wet nitrogen deposition in Chinese terrestrial ecosystems, Sci. Total Environ., 511, 777-785, doi:10.1016/j.scitotenv.2014.12.038, 2015. 